REVISTA DE DERECHO UNED, NÚM. 21, 2017

\title{
DERECHOS DE LOS RECLUSOS EN LA JURISPRUDENCIA DEL TRIBUNAL EUROPEO DE DERECHOS HUMANOS
}

\author{
INMATES' RIGHTS CASELAW IN THE EUROPEAN COURT OF \\ HUMAN RIGHTS
}

José Pablo Sancha DíEz

Resumen: A pesar de las reticencias de los Estados Partes del CEDH de ceder verdaderas porciones de soberanía, o por mejor decir, de ius puniendi estatales, al Consejo de Europa, de la problemática de la ejecución de las sentencias del TEDH al estar en manos del Comité de Ministros, un órgano político, intergubernamental y no jurisdiccional, disociándose así las funciones de juzgar y hacer ejecutar lo juzgado, al carecer el TEDH de facultades anulatorias o revocatorias de las resoluciones y actuaciones internas vulneradoras de derechos recogidos en el Convenio, y de la inexistencia de un catálogo de derechos fundamentales penitenciarios, recogidos por un lado en instrumentos internacionales de ius cogens, es decir, imperativos, y por otro, en Resoluciones y Recomendaciones meramente programáticas, carentes de fuerza obligatoria (vgr. Reglas Penitenciarias Europeas), hemos de reconocer que el TEDH ha venido cumpliendo dignamente el mandato de protección de los derechos y libertades contenidos en el Convenio, y muy especialmente respecto de los derechos de las personas privadas de libertad, y por ende, de los reclusos. Del análisis de la profusa jurisprudencia del TEDH se infiere que las garantías normativas de los presos consagradas en el CEDH, para no ser teóricas e ilusorias, sino reales y efectivas, han tenido que ser ampliadas, perfiladas y completadas por una serie de garantías jurisdiccionales, a través de un sistema o mecanismo jurisdiccional pretoriano, que debemos calificar de verdadera obra pretoriana del TEDH, y que fue 
cristalizándose o codificándose en los diversos Protocolos modificativos. Se convendrá, pues, fácilmente, que el grado de protección de los derechos humanos logrado en el ámbito del Consejo de Europa no tiene parangón en relación con otros sistemas universales o regionales nacidos con el mismo cometido, al albur de los procesos de humanización de los sistemas penitenciarios y de internacionalización de los derechos humanos, que tienen lugar a partir de la Segunda Guerra Mundial.

Abstract: Despite the reluctance of the State Parties of the ECHR to cede actual portions of their sovereignty or, more specifically, of their state ius punendi in favour of the Council of Europe; the issue of the ECHR sentences execution (given to the fact that this is carried out by the Committee of Ministers, a political, intergovernmental and non-judicial organ, dissociating then the tasks of judging and executing what has been judge); the lack of revocation powers by the ECHR regarding the resolutions and internal decisions relating to the violations of the Convention; the lack of an inventory of the fundamental rights included in ius cogens (i.e. imperative) international tools, and the only pragmatic non-compulsory Resolutions and Recommendations (e.g. European Prison Rules), we must admit that the ECHR has been worthily fulfilling its mandate of protecting the rights and freedoms contained in the Convention and, specially, regarding the rights of those deprived of liberty and consequently, of the inmates.

The analysis of the extensive ECHR caselaw infers that the safeguards of the rights of inmates enshrined in the European Council, in order to be real and effective, instead of theoretical or illusory, must have been extended, shaped and completed by a set of judiciary safeguards. This has been possible thanks to a Praetorian judiciary system which must be considered as a real Praetorian work by the ECHR and which has been the object of many amending Protocols. Thus, it can be easily concluded that the level of protection of the human rights achieved by the Council of Europe is unparalleled if compared with other universal or local systems similarly conceived as a result of the human right penitentiary and internationalisation systems developed after the Second World War.

Palabras clave: Convenio Europeo de Derechos Humanos, Tribunal Europeo de Derechos Humanos, jurisprudencia, reclusos, protección jurisdiccional derechos humanos,

Keywords: European Convention of Human Rights, European Court of Human Rights, case of law, inmates, judicial protection of human rights.

Recepción original: 19/05/2017

Aceptación original: 27/10/2017 
Sumario: 1. Introducción. 2. Protección jurisdiccional de los derechos humanos y su proceso de internacionalización: CEDH. 2.1. Problemática de la ejecución de las sentencias del TEDH. 3. Análisis de los derechos de los reclusos en la jurisprudencia del TEDH. 3.1. Jurisprudencia del TEDH sobre los reclusos relativa a España. 3.2. Excursus sobre la doctrina Parot. 3.3. Jurisprudencia del TEDH sobre los reclusos no relativa a España. 4. Consideraciones finales.

Summary: 1. Introduction. 2. Judicial protection of human rights and its internationalisation process: ECHR. 2.1. The execution of the ECHR issue. 3. Analysis of the inmates' rights in the ECHR caselaw. 3.1. The ECHR caselaw regarding inmates in Spain. 3.2. Excursus on the Parot doctrine. 3.3. ECHR caselaw regarding inmates out of Spain. 4. Final remarks.

\section{INTRODUCCIÓN}

En el frenético proceso de liquidación del absolutismo y del Ancien Régime operado por la Revolución Francesa, vio la luz la Declaración de Derechos del Hombre y del Ciudadano adoptada, el 26 de agosto de 1789 por la Asamblea Constituyente francesa, en la que una Exposición de motivos escueta, encomiable, elocuente, y si se permite, atrevida, atestiguaba que «la ignorancia, el olvido o el menosprecio de los derechos del Hombre son las únicas causas de las calamidades públicas y de la corrupción de los Gobiernos. Prescindiendo de antecedentes demasiado remotos ${ }^{1}$, sus inspiradores se basaron en la Declaración de Derechos de Virginia ${ }^{2}$ proclamada el 12 de junio de 1776, en el marco el proceso de independencia de las colonias americanas de la metrópoli británica, y que es considerada como la primera Declaración de derechos humanos de la historia.

La importancia de estos textos radica no sólo en positivizar derechos inalienables y consustanciales a la dignidad humana, propios de

${ }^{1}$ A menudo se considera como el primer documento sobre derechos humanos el llamado "Cilindro de Ciro», redactado en el año 539 a. C. por Ciro El Grande, del Imperio Aqueménida de Persia (antiguo Irán). A nuestro juicio es una afirmación un tanto exagerada, dado que del contenido de la misma no se infiere tal naturaleza.

${ }^{2}$ Se suele citar como precedente normativo de la misma el «Bill of Rights» o Carta de Derechos, impuesta por el Parlamento inglés al príncipe Guillermo de Orange para suceder al Rey Jacobo en 1689. 
cualquier Estado de Derecho ${ }^{3}$, sino en que han sido punto de partida del proceso de internacionalización de los derechos humanos, muy particularmente de la Declaración Universal de Derechos Humanos ${ }^{4}$, y posteriormente en el Convenio para la Protección de Derechos Humanos y de las Libertades Fundamentales (en adelante CEDH) ${ }^{5}$. Proceso en el que nos detendremos en un apartado posterior de este trabajo.

$\mathrm{Ni}$ que decir tiene que el grado de perfección alcanzado por estos dos instrumentos de protección de los derechos humanos, tanto en su dimensión universal como regional, difiere enormemente del que podemos predicar de las Declaraciones de derechos de finales del siglo XVIII, especialmente en lo que se refiere a los mecanismos o garantías jurisdiccionales de los que carecerían en gran medida estas últimas (por no decir en su totalidad). Mas se convendrá fácilmente, sin ambages, que la ausencia de garantías de tal naturaleza en modo alguno empece su carácter inspirador de sucesivos instrumentos de regulación y protección de derechos humanos.

Ha sido en el ámbito de la protección jurisdiccional de los humanos donde se ha dejado sentir intensamente la labor del Tribunal Europeo de Derechos Humanos, al interpretar y aplicar los preceptos del $\mathrm{CEDH}^{6}$, desarrollando una función garantista de las personas privadas de libertad, y por ende situadas en una posición de especial vulnerabilidad, y que constituye el objeto del presente estudio.

\section{PROTECCIÓN JURISDICCIONAL DE LOS DERECHOS HUMANOS Y SU PROCESO DE INTERNACIONALIZACIÓN: $\mathrm{CEDH}$}

El proceso de internacionalización de los derechos humanos tiene lugar en primer lugar a nivel mundial, para luego concretarse a nivel regional europeo, precisamente en el CEDH. De forma somera diremos que en el seno de la Organización de las Naciones Unidas, se adoptó la DUDH como respuesta por la Comunidad Internacional de

${ }^{3}$ La Declaración de Derechos del Hombre y el Ciudadano establecía en su artículo 7 que «ningún hombre podrá ser arrestado o detenido, salvo en los casos determinados por la Ley y en la forma determinada por ella».

${ }^{4}$ Adoptada en el seno de la Organización de las Naciones Unidas por su Asamblea Nacional el 10 de diciembre de 1948.

${ }^{5}$ Adoptado en Roma el 4 de noviembre de 1950 por los integrantes del Consejo de Europa.

${ }^{6}$ En el Preámbulo del CEDH se reconoce que uno de los medios para lograr una estrecha unión entre los países del Consejo de Europa es precisamente «la protección y el desarrollo de los derechos humanos y de las libertades fundamentales». 
las atrocidades cometidas y vulneraciones de los derechos humanos perpetradas durante la Segunda Guerra Mundial, especialmente por el régimen nazi en los campos de concentración repartidos por toda la zona ocupada.

En ese orden de cosas mediante la firma del Tratado de Londres en 1949 un grupo de diez países europeos ${ }^{7}$ crea el Consejo de Europa cuyo objetivo radica, como ya hemos advertido, entre otros, en la salvaguardia y desarrollo de los Derechos Humanos y Libertades Fundamentales. Fruto de tales intenciones se firma en Roma el 4 de noviembre de 1950 el Convenio Europeo para la Protección de los Derechos Humanos y de las Libertades Fundamentales, y que ha sido objeto de catorce protocolos que lo completan. Debe llamarse la atención sobre el número once ${ }^{8}$ que ha instituido el «Tribunal Europeo de Derechos Humanos», tras la refundición de dos órganos existentes hasta el momento como eran la Comisión y el Tribunal de Derechos Humanos, con la finalidad de mantener y reforzar la eficacia de la protección de los derechos humanos en el ámbito del Convenio. Además la modificación operada en el Convenio a raíz de dicho Protocolo, legitima a los nacionales de un Estado Parte ${ }^{9}$ (previo agotamiento de las vías jurisdiccionales internas o cumplimiento previo el principio de subsidiariedad) a obtener el reconocimiento de la vulneración por este último de un derecho garantizado por el Convenio, aunque no sea su Estado de origen, superando así la clásica concepción del derecho internacional como fuente de obligaciones netamente interestatales.

A diferencia de los órganos instituidos por otros tratados internacionales, como la Convención de las Naciones contra la Tortura y otros tratos o Penas Crueles o Degradantes ${ }^{10}$ que crearon el Comité contra la Tortura (CAT), Subcomité para la Prevención de la Tortura o Relatoría Especial sobre la Tortura, y que en el ámbito europeo tiene su correlato en el Convenio Europeo para la Prevención de la Tortura y de las Penas o Tratos Inhumanos o Degradantes de 1987

${ }^{7}$ Reino Unido, Noruega, Suecia, Bélgica, Dinamarca, Países Bajos, Luxemburgo, Italia, Irlanda y Francia; entre los que no se encontraba España, que como casi siempre llega tarde a las citas históricas. Componen en la actualidad el Consejo de Europa cuarenta y siete estados, España es miembro desde el año 1977 (24 de noviembre).

${ }^{8}$ Ratificado por España mediante Instrumento de Ratificación publicado en el BOE núm. 152 de 26 de junio de 1998.

${ }^{9} \mathrm{El}$ artículo 34 el CEDH señala «El Tribunal podrá conocer de una demanda presentada por cualquier persona física, organización no gubernamental o grupo de particulares que se considere víctima de una violación, por una de las Altas Partes Contratantes, de los derechos reconocidos en el Convenio o sus Protocolos...».

${ }^{10}$ Adoptada en el seno de las Naciones Unidas el 10 de diciembre de 1984, entrando en vigor el 26 de junio de 1987. Fue ratificada por nuestro país en fecha 9 de noviembre de 1987. 
(ratificado por España el 2 de mayo de 1989, BOE núm. 159 de 5 de julio de 1989), el órgano al que se atribuye la misión de proteger los derechos reconocidos en el propio $\mathrm{CEDH}$ es un órgano jurisdiccional, esto es, un verdadero tribunal. Lo que ha propiciado que la doctrina $^{11}$ haya distinguido que al abrigo del artículo 3 del CEDH, este último ha dado lugar a dos sistemas complementarios de control: el tradicional sistema jurisdiccional y el sistema preventivo nacido del Convenio de 1987.

De suerte que los mecanismos de garantías jurisdiccionales implementados por el Consejo de Europa ha dispensado una protección más completa y eficaz de los derechos garantizados en aquél, que la ofrecida por otros sistemas de protección de derechos humanos, como el instituido en el seno de las Naciones Unidas, que sí cuentan como estamos viendo, con un altísimo nivel de perfeccionamiento en las garantías de índole normativa o jurídica. Hecho este último que se constata con la adopción el Pacto Internacional de Derechos Civiles y Políticos ${ }^{12}$ en la década de los años sesenta, que llega a proclamar en su artículo décimo que «toda persona privada de libertad será tratada humanamente y con el respeto debido a la dignidad inherente al ser humano».

Existen asimismo otros documentos jurídicos internacionales que el propio TEDH suele invocar en sus Sentencias ${ }^{13}$ como la Convención para la Protección de todas las personas contra las desapariciones forzadas ${ }^{14}$, de especial aplicación a las personas que han sido privadas de libertad, no admitiendo derogaciones al principio general consagrado en dicho texto (nadie puede ser sometido a una desaparición forzada), ni siquiera «estado de guerra o amenaza de guerra, inestabilidad política interna cualquier otra emergencia pública».

${ }^{11}$ Santamaría Arinas, R. y Bolaño Piñeiro, M. ${ }^{a}$ C. (2015). «Artículo 3. Prohibición de la tortura», en Lasagabaster Herrarte, I. (dir.). Convenio Europeo de Derechos Humanos: comentario sistemático, Madrid, Editorial Aranzadi S: A., págs. 54 a 95.

${ }^{12}$ De fecha 19 de diciembre de 1966. Ratificación por España mediante instrumento de fecha de 13 de abril de 1977 (BOE núm. 103 de 30 de abril de 1977).

${ }^{13}$ Asunto El-Masri c. Ex-República Yugoslava de Macedonia de 13 diciembre de 2012 y en la que se alega por el demandante haber sido sometido por el Gobierno Macedonio a una desaparición forzada, al practicarse su detención en un paso fronterizo de aquél y ser entregado, en ausencia de control judicial de la medida, a la CIA, que lo retuvo durante cuatro meses en Kabul (Afganistán) en una "pequeña celda de cemento, de suciedad repugnante«; tal y como se afirma en el Informe «Marty» de 2007 emitido en el desarrollo de un serie de investigaciones oficiales efectuadas por la Asamblea Parlamentaria del Consejo de Europa.

${ }^{14}$ Aprobada el 20 de diciembre de 2006 y en vigor desde el 23 de diciembre de 2010. 
Como señala, respecto de los preceptos del CEDH, Lezertúa Rodríguez ${ }^{15}$, "no se trata de derechos específicos garantizados al preso por el hecho de estar preso sino del disfrute, en medio carcelario, por parte del preso, de los derechos y libertades reconocidos de manera general a todo ser humano por el CEDH». Por eso no hallamos un solo Protocolo de los dieciséis que han modificado al citado Convenio, que tenga por objeto específico a las personas privadas de libertad o reclusos, lo que no es óbice para que varios de sus preceptos sean de especial aplicación a los presos: el artículo 3 prohibiendo la tortura o ser sometido a penas o tratos inhumanos o degradantes, la interdicción de la esclavitud y los trabajos forzados (artículo 4), la protección de la libertad y seguridad, el único que contiene disposiciones específicas para personas detenidas ${ }^{16}$, el derecho a un proceso equitativo (derecho a un proceso público con todas las garantías) del artículo 6, que incluye el respeto a la presunción de inocencia en su apartado segundo, la proclamación del viejo brocardo «nullum crimen sine lege, nulla poena sine lege «, del artículo 7 que proclama el principio de legalidad de los delitos y las penas, el derecho al secreto al secreto de las comunicaciones y a la intimidad (aunque proclamado de forma genérica con la expresión toda persona») y el artículo 13 que como cláusula de cierre del sistema, reconoce igualmente un derecho de recurso efectivo a nivel interno en caso de vulneración de los derechos citados.

Habrá pues que cuestionarse, cómo a la vista de la perfección técnica y de las garantías normativas contenidas en los diversos instrumentos internacionales, no exista un tratado internacional, con naturaleza de ius cogens a nivel europeo que de forma global regule los derechos de los presos. La respuesta ha de encontrase como afirma Lezertúa ${ }^{17}$ "por la estrecha vinculación existente entre política penal y soberanía estatal, de la que deriva una mayor resistencia de los Estados a asumir obligaciones internacionales en el ámbito penal y penitenciario».

Todo ello sin perjuicio de que el proceso de humanización de las prisiones y de las condiciones de los reclusos vivido especialmente en el viejo continente, haya cristalizado en instrumentos específicos de protección de los presos, con el carácter de soft law o derecho blando, es decir, no imperativo (ius cogens), para los Estados Parte signatarios

${ }^{15}$ Lezertúa Rodríguez, M. (1998). «Los derechos de los reclusos en virtud del Convenio Europeo de Derechos Humanos». Eguzkilore (Cuaderno el Instituto Vasco de Criminología). Número extraordinario 12. págs. 135 a 165.

${ }^{16}$ El artículo 5 del CEDH establece: «1. Toda persona tiene derecho a la libertad y a la seguridad. Nadie puede ser privado de su libertad, salvo en los casos siguientes y con arreglo al procedimiento establecido por la ley».

${ }^{17}$ Lezertúa Rodríguez, M. (1998). «Los derechos de los reclusos...» op. cit., pág. 137. 
de los mismos, y funcionan a modo de recomendaciones y directrices que han inspirado y enriquecido las legislaciones penitenciarias europeas y por supuesto española ${ }^{18}$. Tal es el caso de las Reglas Penitenciarias Europeas, que son la extrapolación de las Reglas Mínimas para el Tratamiento de los reclusos ${ }^{19}$ al ámbito europeo.

\subsection{Problemática de la ejecución de las sentencias del T E. D. H.}

El mecanismo de ejecución de las Sentencias del TEDH por los Estados demandados y condenados, en su caso, está previsto en el artículo 46 del CEDH bajo la rúbrica "Fuerza obligatoria y ejecución de las sentencias», comprometiéndose a acatar aquellas las mismas los que han sido parte en el procedimiento y de modo especial, el Estado demandado en su condición de Alta Parte Contratante; encomendándose al Comité de Ministros del Consejo de Europa velar por la efectividad de su ejecución, toda vez que no corresponde al órgano jurisdiccional que ha dictado la sentencia. Es más la sentencia estimatoria es de naturaleza declarativa, por lo que no puede el TEDH revocar, anular, o corregir las resoluciones o actuaciones de las autoridades u órganos judiciales internas ${ }^{20}$, dado que el TEDH no es un órgano de apelación, ni de revisión, ni de casación. Corresponde al Estado demandado adoptar las medidas necesarias para asegurar la efectividad de los pronunciamientos de la sentencia. En el caso de que no fuera posible la "restitutio in integrum», restableciendo al reclamante en la integridad de su derecho, debería por el Estado demandado darse puntual y exacto cumplimiento a la satisfacción equitativa impuesta por el

${ }^{18}$ De lege data nuestra legislación penitenciaria se encuentra a la vanguardia en los ordenamientos penitenciarios contemporáneos y es tributaria de las corrientes más avanzadas de la Ciencia penitenciaria. Una contribución fundamental en la situación actual de nuestra legislación penitenciaria se debe, sin duda, al proceso de internacionalización que ha sufrido los derechos fundamentales de los reclusos y a la posterior recepción de tales convenios y tratados internacionales en nuestro ordenamiento jurídico.

${ }^{19}$ Resolución ECOSOC núm. 663 C (XXIX).

${ }^{20}$ A diferencia del TEDH, nuestro Tribunal Constitucional, de conformidad con el artículo 55 de su Ley Orgánica, posee las siguientes competencias: «1. La sentencia que otorgue el amparo contendrá alguno o algunos de los pronunciamientos siguientes:

a) Declaración de nulidad de la decisión, acto o resolución que hayan impedido el pleno ejercicio de los derechos o libertades protegidos, con determinación, en su caso, de la extensión de sus efectos.

b) Reconocimiento del derecho o libertad pública, de conformidad con su contenido constitucionalmente declarado.

c) Restablecimiento del recurrente en la integridad de su derecho o libertad con la adopción de las medidas apropiadas, en su caso, para su conservación». 
TEDH, normalmente mediante el cumplimiento de obligaciones de naturaleza pecuniaria.

En lo que concierne a nuestro país, prima facie, no cabe duda que estamos en presencia de una obligación jurídica internacional, de naturaleza imperativa adquirida por nuestro Estado ${ }^{21}$ al amparo del artículo $96^{22}$ de nuestra Carta Magna, de suerte que una vez ratificado el CEDH se integra en nuestro ordenamiento jurídico. Sin embargo esta afirmación inicial ha sido matizada cuando se advierte que no se ha realizado una «transferencia de competencias» del artículo 117.3 de nuestra Constitución, en conexión con el artículo 93, a favor del Consejo de Europa, y en particular del TEDH, como ya puso de manifiesto amplio sector de la doctrina patria ${ }^{23}$. Ello supone inexorablemente que la configuración de la naturaleza del TEDH sea la de un órgano jurisdiccional internacional, no integrado en nuestro Poder Judicial, dificultando en mayor medida la ejecución de sus sentencias, máxime cuando carece de medios coercitivos para logar su cumplimiento, dado que «es común que las decisiones judiciales internacionales carezcan de fuerza ejecutiva ${ }^{24}$. Cuanto venimos diciendo no será óbice para manifestar sin reticencia alguna el «obligado cumplimiento de la doctrina del TEDH por nuestros Tribunales en virtud del artículo 10.2» ${ }^{25}$.

La problemática de la eficacia directa de las sentencias del TEDH se ha recrudecido especialmente en aquellos casos en los que este último reconocía la vulneración de un precepto del CEDH por uno de los Estados parte, que imponía la revisión de procesos fenecidos en la jurisdicción interna y que afectaba a cuestiones de las que se predicaba el carácter de cosa juzgada (res iudicata). La totalidad de la doctrina procesalista española venía con insistencia demandando un cauce procesal idóneo para conseguir la ejecución directa de las sentencias del TEDH en estos casos, particularmente cuando el de-

${ }^{21}$ En la Declaración de 26 de septiembre de 1979 aneja al Instrumento de ratificación se declaraba como obligatoria la jurisprudencia del TEDH para conocer de todos los asuntos relativos a la interpretación y aplicación del CEDH.

22 "Los Tratados Internacionales válidamente celebrados, una vez publicados oficialmente en España, formaran parte del ordenamiento jurídico".

${ }^{23}$ IzQuiERdo SANS, C. (1997), «El carácter no ejecutivo de las Sentencias del Tribunal Europeo de Derechos Humanos (Comentarios a la STS, 1. a , del 20 de noviembre de 1996)», en Derecho Privado y Constitución, núm. 11 enero-diciembre, CEPC, págs. 351 a 377.

${ }^{24}$ Soria JimÉNEZ, A. (1992). «La problemática ejecución de las Sentencias del Tribunal Europeo de Derechos Humanos. Análisis de la STC 245/1991». Revista Española de Derecho Constitucional. Año 12, núm. 36, septiembre-diciembre, págs. 313 a 356.

${ }^{25}$ Gómez de Liaño Fonseca-Herrero, M. (2006). «La protección jurisdiccional de los derechos fundamentales en la Unión Europea». Revista de Derecho de la Unión Europea. Núm. 11, 2. ${ }^{\circ}$ semestre, págs. 61 a 78. 
recho vulnerado por la jurisdicción nacional era el derecho a un proceso equitativo proclamado en el artículo 6 del Convenio, que en realidad es idéntico al contemplado en el artículo 24.2 de nuestra «norma normarum».

Paradójicamente en el fundamento jurídico tercero de la STC 245/1991(asunto Barberá, Messegué, Jabardo) se reconoce que el carácter declarativo de las sentencias del TEDH no supone «la carencia de todo efecto interno de la declaración realizada por dicho Tribunal sobre la existencia de infracción de un derecho reconocido en el Convenio» al amparo del artículo 10.2 de la Constitución, que obliga a interpretar las normas relativas a los derechos fundamentales y libertades públicas contenidas en ella, de conformidad con lo establecido en los tratados y acuerdos internacionales sobre las materias ratificadas por España, entre ellos necesariamente el CEDH. Se trataba pues, de la anulación ${ }^{26}$ por el Alto Tribunal de resoluciones del Tribunal Supremo y de la Audiencia Nacional recaídas en un proceso penal, viéndose obligado, a nuestro modo de entender innecesariamente, a reiterar, el carácter declarativo de las sentencias del TEDH y sobre todo que no existe precepto del Convenio de Estrasburgo que obligue al Estado español a revisar aquellas resoluciones penales firmes que hayan incurrido en conculcación del algún artículo de aquél, en este caso del derecho a un proceso equitativo. Y decimos a nuestro juicio innecesariamente puesto que bastaba invocar la cláusula interpretativa del artículo 10.2 de la Constitución, toda vez que los recurrentes en amparo $^{27}$ se encontraban sufriendo penas privativas de libertad en virtud de un proceso penal con vulneración de las garantías contempladas en el artículo 24.2 de nuestra «lex superior». A mayor abundamiento el mismo TEDH reconoció expresamente violación de las garantías procesales de los condenados en nuestro país, como consecuencia de «la brevedad del juicio y el que muchas importantes piezas y elementos de prueba no se adujeran y discutieran adecuadamente en el juicio oral». Desgraciadamente nuestro Tribunal Constitucional no solo no ha confirmado esta doctrina con posterioridad, sino que se ha apartado claramente de la misma.

${ }^{26}$ El magistrado del TC, Gimeno Sendra, en voto particular señaló «somos el primer Tribunal Constitucional europeo que ha procedido de facto a ejecutar una sentencia del TEDH mediante la anulación de sentencias de nuestro Poder Judicial».

${ }^{27} \mathrm{Y}$ al mismo tiempo demandantes ante el TEDH, en el asunto Barbera-MeseguéJabardo c. España de fecha 6 de diciembre de 1998, y en la que se declaró la vulneración del artículo 6.1 del CEDH, en su vertiente de un proceso justo y con todas las garantías. 
Gimeno Sendra ${ }^{28}$ subraya como nuestro Tribunal Constitucional tuvo ocasión de manifestarse en la Sentencia 245/1991, de 16 de diciembre, sobre esta cuestión, "sugiriendo la instauración de un explícito motivo del recurso de casación, habida cuenta de que su viabilidad como hecho nuevo, ha sido reiteradamente desestimada por la jurisprudencia». Añade dicho autor que la anulación del AAN de la Sección 1. ${ }^{a}$ de 6 de junio de 2008 por la STEDH de 21 de octubre de 2013, asunto Del Río Prada c. España, ha convertido de facto al TEDH en una especie de TC europeo, por lo que las resoluciones del Tribunal de Estrasburgo deben ejecutarse por el TC español; habida cuenta de la diferente naturaleza del fallo meramente declarativo contenido en la STEDH de fecha 6 de diciembre de 1988 (asunto Barberá, Messegué, Jabardo c. España), en relación con el fallo de condena contenido en la STEDH relativo al asunto Del Río Prada c. España, ordenando la puesta en libertad de la demandante, "haciendo gala de una cierta e injustificada desconfianza».

De suerte que la situación de inexistencia de un mecanismo o cauce procesal que permitiera la ejecución de las sentencias del TEDH, y que lleve consigo la anulación o revocación de una resolución judicial dictada por los tribunales españoles, no podía dilatarse por más tiempo, y quizás un tanto acuciado por la sentencia del TEDH en el asunto Del Río Prada c. España, el Tribunal Supremo a través de un acuerdo no jurisdiccional de su Sala de lo Penal, de fecha 21 de octubre de 2014, esbozó una posible vía de solución, en tanto que no existía una expresa previsión legal para la efectividad de las sentencias dictadas por el TEDH, consistente en acudir al recurso de revisión previsto en el artículo 954 de la Ley de Enjuiciamiento Criminal, pudiendo, llegado el caso, a declarar la nulidad de una sentencia penal condenatoria, cuando se declare por el TEDH la vulneración de un precepto del CEDH.

$\mathrm{Al}$ efecto de solventar esa laguna legislativa en nuestro ordenamiento jurídico procesal penal, que no en otros órdenes jurisdiccionales, y que largamente había sido reclamado por la doctrina procesalista patria, se aprobó el pasado 15 de marzo de 2015, por el Consejo de Ministros un proyecto de reforma de la Ley de Enjuiciamiento Criminal, que ha desembocado la Ley 41/2015 de 5 de octubre, de modificación de la Ley de Enjuiciamiento Criminal para la agilización de la justicia penal y el fortalecimiento de las garantías procesales, por la

${ }^{28}$ Gimeno Sendra, V. (2014). «La doctrina Parot y el principio de legalidad». Diario La Ley, núm. 8037, Sección Doctrina, ref. D 145, págs. 1 a 10. 
que se procede a dar una nueva redacción al artículo 954.3 de nuestra vetusta ley de ritos $^{29}$.

\section{ANÁLISIS DE LOS DERECHOS DE LOS RECLUSOS EN LA JURISPRUDENCIA DEL TEDH}

Para un mejor análisis y comprensión de los derechos de los pe$\operatorname{nados}^{30}$ a la luz de la jurisprudencia del TEDH, debemos situar aquéllos en el marco de las relaciones de sujeción especial. Éstas tienen su origen en los juristas del llamado Estado- policía del siglo XIX, y muy particularmente en los trabajos de Jellinek, Laband, y Otto Mayer, es decir, en la Dogmática alemana.

Como pone de relieve Reviriego Picón ${ }^{31}$ nuestro Alto Tribunal tuvo ocasión de manifestarse por primera vez al respecto en la STC 74/1985, de 18 junio, en la que calificó expresamente de relación de sujeción especial, la existente entre la Administración penitenciaria y el interno en un centro penitenciario, al ejercitarse por aquélla la potestad sancionatoria disciplinaria, remitiéndose a los artículos 104 y siguientes del Reglamento penitenciario, en lo que se refiere a su ejercicio y límites. Del mismo modo volvió a recalcar dicha naturaleza en la Sentencia 175/2000, de 26 de junio, FJ 2. ${ }^{\circ}$, con ocasión del derecho al secreto de las comunicaciones de los reclusos. A pesar de que nuestro Tribunal Constitucional acuda a esta figura reiteradamente, ha

${ }^{29}$ El artículo 954. 3 LECr dispone: «Se podrá solicitar la revisión de una resolución judicial firme cuando el Tribunal Europeo de Derechos Humanos haya declarado que dicha resolución fue dictada en violación de alguno de los derechos reconocidos en el Convenio Europeo para la Protección de los Derechos Humanos y Libertades Fundamentales y sus Protocolos, siempre que la violación, por su naturaleza y gravedad, entrañe efectos que persistan y no puedan cesar de ningún otro modo que no sea mediante esta revisión. En este supuesto, la revisión sólo podrá ser solicitada por quien, estando legitimado para interponer este recurso, hubiera sido demandante ante el Tribunal Europeo de Derechos Humanos. La solicitud deberá formularse en el plazo de un año desde que adquiera firmeza la sentencia del referido Tribunal».

${ }^{30}$ Debe entenderse por penado, a la luz de la jurisprudencia del TEDH, la persona» privada de libertad como consecuencia de pronunciamientos judiciales condenatorios que supongan imposición de penas o medidas de seguridad» asunto Droogenbroeck c. Bélgica, de 24 de junio de 1982. En el asunto Matutes c. Alemania, de fecha 13 de enero de 2011, se considera penado a quien "ha sido encontrado culpable de la comisión de un delito y ser sujeto de la imposición de una pena que conlleva privación de libertad».

${ }^{31}$ Reviriego Picón, F. (2008). Los derechos de los reclusos en la jurisprudencia constitucional, Madrid. Editorial Universitas, págs. 35 a 44. 
sido objeto de feroces críticas en la doctrina actual ${ }^{32}$. A mayor abundamiento, el profesor Reviriego la considera una construcción innecesaria en nuestro ordenamiento jurídico, propugnando la propuesta de su abandono definitivo y opta (en aras de una más efectiva protección de los derechos fundamentales de los reclusos y un mejor cumplimiento del mandato constitucional de otorgar a las penas privativas de libertad un fin resocializador), por integrar el contenido de la relación jurídico-penitenciaria con el artículo 25.2 CE, fijándose como límites a la misma el contenido del fallo condenatorio, el sentido de la pena y la ley penitenciaria ${ }^{33}$.

\subsection{Jurisprudencia del TEDH sobre los reclusos relativa a España}

Prohibición de la tortura y de tratos y penas inhumanos y degradantes (art $3 \mathrm{CEDH})$

Por otro lado, la prohibición contenida en este artículo, así como en los artículos 4 y 7 es absoluta, no admitiéndose excepción alguna. Sin embargo, como destaca Fernández Sánchez ${ }^{34}$, la excepción (causa de muertes resultantes de actos lícitos de guerra) contemplada en el párrafo segundo del artículo 15, respecto al derecho a la vida del artículo 2 , es un "contrasentido», toda vez que la vida constituye el bien jurídico superior a proteger. Desde un punto de vista terminológico debe mantenerse, con el citado autor, que la expresión «derogación» empleada por el citado artículo 15 es desafortunada, debiendo entenderse como «suspensión» de las disposiciones del convenio previo cumplimiento del procedimiento previsto en el mismo.

${ }^{32}$ Reviriego Picón, F. (2008), op. cit., pág. 37; en la que se traen a colación las vertidas por Mapelli Caffarena que afirma que «las relaciones de sujeción especial se corresponden a una visión retributiva de los fines de la pena» y por Díez-Picazo quien señalará que «esta noción doctrinal no siempre resulta coherente con los postulados del Estado democrático de Derecho».

${ }^{33}$ Reviriego Picón, F. (2008), op. cit., pág. 43; coincidiendo con Lasagabaster quien entiende que» la utilización de las relaciones de sujeción especial provoca más problemas de los que evita, es caprichosa, y especialmente produce una gran inseguridad jurídica».

${ }^{34}$ Fernández SÁnchez, P. A. (2014). «La jurisprudencia del Tribunal Europeo de Derechos Humanos en torno a España: Una historia de encuentros y desencuentros». García Roca, J y Santolaya Machetti, P. (coords.), La Europa de los Derechos: Convenio Europeo de Derechos Humanos, Madrid, Centro de Estudios Políticos y Constitucionales, págs. 613-624. 
El derecho consagrado en este precepto ha sido catalogado de inderogable y absoluto por la doctrina internacionalista, en concreto por Cassese y McDonald, y que luego ha sido mantenido por la jurisprudencia del TEDH, como veremos a lo largo de este trabajo. Acertadamente señala Salado Osuna ${ }^{35}$ que, aun cuando el Convenio no contiene una definición de tortura ni de tratos inhumanos o degradantes, ha permitido jugar al Tribunal de Estrasburgo un papel esencial a la hora de configurar el contenido de tales conceptos. Así, a pesar de que un sector doctrinal entienda que el «sujeto activo cualificado» de dicha violación deba ser necesariamente un funcionario público (en el ejercicio de funciones públicas, o con su consentimiento o aquiesciencia), el propio TEDH, "a través una interpretación sistemática de los artículos 1 y 3, ha afirmado que los actos cometidos por los particulares pueden ser constitutivos de una violación del artículo 3», como nos recuerda la citada autora. La dicción del artículo 3 ha permitido declarar su vulneración por la falta de atención médica a los reclusos, a pesar que no se haya reconocido el derecho a la salud de forma expresa en el Convenio ${ }^{36}$. No ampara el citado precepto derechos de naturaleza económica o social, como ha reconocido explícitamente el TEDH ${ }^{37}$. Por el contrario, la brevedad del articulo 3 ha sido interpretada por la doctrina como la voluntad de las Partes de no introducir más detalles para no limitar el alcance de la prohibición.

La primera sentencia condenatoria a nuestro país por vulneración, en palabras del propio TEDH, de uno de los más importantes e invocados artículos del CEDH junto con el que garantiza el derecho a la vida (art. 2), tuvo lugar en el asunto Martínez Sala y otros c. España, de fecha 2 de noviembre de 2.004 , y que venía precedida de numerosos informes de organismos internacionales ${ }^{38}$ en los que se reflejaba

${ }^{35}$ Salado Osuna, A. (2014). «Los tratos prohibidos en el artículo 3 del Convenio Europeo de Derechos Humanos». García Roca, J y Santolaya Machetti, P. (coords.), La Europa de los Derechos: Convenio Europeo de Derechos Humanos, Madrid, Centro de Estudios Políticos y Constitucionales, págs. 85 a 112.

${ }^{36}$ Se citan a modo ejemplificativo, extraídos de la jurisprudencia del TEDH, por Salado Osuna, la falta de atención médica a una heroinómana encarcelada, o a un recluso que padecía cirrosis.

${ }^{37}$ Santamaría Arinas, R. y Bolaño Piñero, M. ${ }^{a}$ C. (2015) op. cit., págs. 54 a 95; así lo declaró la Gran Sala por mayoría en el asunto N. c. Reino Unido.

${ }^{38}$ El Comité Europeo para la Prevención de la Tortura y Penas o Tratos inhumanos o degradantes así lo constata en su informe emitido a raíz de su visita a nuestro país durante el año 2001. 
la disconformidad con la forma en que el Reino de España combatía las actividades terroristas ${ }^{39}$.

De suerte que la primera y única sentencia condenatoria a nuestro Estado por la conculcación del artículo 3 en su vertiente material, se produjo en el asunto Irribarren Pinillos c. España. En la sentencia de fecha 8 de enero de 2009, el TEDH consideró que la jurisdicción penal española no había determinado la eventual responsabilidad del demandante por los daños sufridos ${ }^{40}$ y la jurisdicción contenciosoadministrativa del mismo modo no había tampoco investigado cual era en su caso la parte de responsabilidad del demandante. Al igual que en el asunto Martínez Sala y otros, nuestro Tribunal Constitucional inadmitió el recurso de amparo formulado.

En ese orden de cosas en el asunto San Argimiro Isasa c. España, de fecha 28 de septiembre de 2010, el TEDH declara haber lugar a la violación del artículo 3 del Convenio en su vertiente procesal. A mayor abundamiento pone de manifiesto que es precisamente la falta de investigación efectiva por las jurisdicciones españolas la que impide disponer de elementos que permitan más allá de toda duda razonable establecer que el demandante fue objeto de malos tratos. El TEDH expresamente, y no sin estupor, declaró que las «jurisdicciones internas rechazaron medios de prueba que habrían podido contribuir a la

${ }^{39}$ Los demandantes alegaron que habían sido objeto de torturas físicas y psicológicas y tratos inhumanos y degradantes durante su detención, así como de la insuficiente investigación llevada a cabo por el Juez de Instrucción sobre tales actos. Nuestro Tribunal Constitucional inadmitió el recurso de amparo. En la citada sentencia declaró el TEDH haber lugar a la violación del artículo 3 en su vertiente procesal, esto es, por haberse denegado en concreto las solicitudes de práctica de prueba de los demandantes, las declaraciones de los policías que los interrogaron, la incorporación a los autos de las declaraciones de estos últimos y de los informes vertidos en el procedimiento seguido por delitos de terrorismo y pertenencia a banda armada que se había seguido contra aquéllos. Sin embargo, no entendió vulnerado el artículo 3 en su vertiente material o sustantiva, toda vez que de los informes redactados por los médicos forenses durante la detención y los emitidos por otros facultativos después de puestos en libertad los demandantes, no existían pruebas suficientes para constatar la existencia efectiva de malos tratos.

${ }^{40}$ Los daños alegados por el demandante nacen de la participación de este en una serie de altercados acaecidos en Pamplona el 15 de diciembre de 1991, en los que fue gravemente herido por el lanzamiento de un bote de humo a corta distancia por la policía antidisturbios. Las diligencias previas abiertas fueron sobreseídas por la ausencia de identificación del autor. Sin embargo, por su parte la Audiencia Nacional declaró haber lugar a responsabilidad patrimonial del Estado. Por su parte el Tribunal Supremo entendió no desproporcionada la actuación de los agentes antidisturbios, habiendo contribuido a crear el demandante la situación de la que fue víctima. 
aclaración de los hechos, y más precisamente, a la identificación y castigo de los responsables, como exige la jurisprudencia del Tribunal». ${ }^{41}$

En semejantes términos en el asunto Beristaín Ukar c. España de fecha 8 de marzo de 2011, el TEDH estima de nuevo que, al no efectuarse por las Autoridades españolas una investigación detallada y eficaz de los hechos alegados por el demandante, se ha vulnerado el artículo 3 del Convenio en su versión procesal ${ }^{42}$. Distinción que empezó a efectuarse por el Tribunal de Estrasburgo a partir de la segunda mitad de la década de los años noventa.

Al hilo de la distinción de la vulneración del artículo 3 del Convenio en su vertiente material y procesal, y con ocasión de la sentencia que venimos comentando, López Bofill ${ }^{43}$ resalta la dificultad de compatibilizar la prohibición absoluta de tortura recogida el Convenio, con la condena a Estados signatarios por la vulneración del citado artículo, en su versión procedimental, esto es, por la ausencia de investigación profunda y efectiva sobre las alegaciones de malos tratos vertidas por los demandantes. En aquellos casos en los que no pueda probarse «más allá de toda duda razonable» la existencia de tales malos tratos, el TEDH recurre a la fórmula de la vulneración procesal del artículo 5 para lograr de algún modo la protección del demandante, toda vez que por el

${ }^{41} \mathrm{El}$ demandante fue detenido por presuntos delitos de terrorismo, pertenencia a banda armada, tenencia de armas y explosivos y tentativa de asesinato, alegando que había sufrido malos tratos durante su estancia en la Dirección General de la Guardia Civil en Madrid en mayo de 2002, en la que estuvo incomunicado durante cinco días. De forma incomprensible el Juez de Instrucción, y la propia Audiencia Provincial acordaron el sobreseimiento, e incluso el propio Tribunal Constitucional incomprensiblemente, como en los asuntos anteriormente examinados, declaró la inadmisión del recurso de amparo, al afirmar que las jurisdicciones ordinarias habían considerado, de modo ampliamente motivado y razonable, que los malos alegados no se habían probado.

${ }^{42}$ En particular afirma el TEDH que el Juez instructor que conoció de los malos tratos alegados por el demandante, solo tuvo en consideración dos de los cinco informes emitidos por el médico forense, sin dar audiencia al detenido, ni ordenar nuevos peritajes. Sin embargo, el Tribunal Constitucional inadmitiendo el recurso de amparo, llegó a afirmar que las alegaciones de malos tratos del demandante eran inverosímiles. Huelga decir que estamos en presencia de otra sentencia condenatoria por violación del artículo 3 del Convenio como consecuencia de la lucha contra el terrorismo en nuestro país, a pesar de todas las recomendaciones en la materia que se venían efectuando desde diversos foros e instancias internacionales europeas, y de la doctrina jurisprudencial del TEDH, reiterada hasta la saciedad, consistente en que uno de los valores fundamentales de las sociedades democráticas lo constituye el artículo 3 del $\mathrm{CEDH}$, que no admite excepciones, ni siquiera en circunstancias muy difíciles, como la lucha contra el terrorismo.

${ }^{43}$ López Bofill, H. (2012). «Prohibición de tortura: violación del artículo 3 del convenio europeo de derechos humanos desde el punto de vista procedimental (comentario a la STEDH de 8 de marzo de 2011, Beristain Ukar contra España)». Revista Aranzadi Doctrinal, 10/2012, págs. 85-94. 
Estado demandado no se ha llevado a cabo labor alguna de investigación. A juicio de López Bofill podría achacarse, la distinción entre ambas vulneraciones llevada a cabo por el propio TEDH, a la convivencia en el seno del Consejo de Europa de «democracias avanzadas y Estados con precarios sistemas de protección de derechos humanos».

La siguiente resolución condenatoria contra España no guardaba relación con los delitos de terrorismo y la actuación de las Fuerzas y Cuerpos de Seguridad del Estado. En el asunto B. S. c. España de fecha 24 de julio de 2012, se condena a España por una vulneración de artículo 3 en su vertiente procesal, habida cuenta de que las alegaciones de malos tratos denunciadas no fueron objeto de una investigación profunda y efectiva, lo que impidió en gran medida determinar más allá de toda duda razonable, sí se habían producido los malos tratos sobre la demandante, residente legal en España y de origen nigeriano, por dos agentes de policía que patrullaban por la zona.

No hubo de transcurrir demasiado tiempo para que de nuevo recayera sentencia condenatoria en el asunto Otamendi Eguiguren c. España de fecha 16 de octubre de $2012^{44}$. El TEDH se vio en la obligación de recordar al Estado español la necesidad imperiosa de adoptar las recomendaciones formuladas por Comité Europeo para la Prevención de la Tortura $(\mathrm{CPT})^{45}$, en los casos de detenciones preventivas y sometidas a prohibición de incomunicación.

${ }^{44}$ Para más concisión se trataba de la detención de un presunto miembro de la banda terrorista ETA, al que se sometió a detención incomunicada, durante cinco días, sin que pudiera informar de su situación a persona alguna, no pudiendo entrevistarse con el abogado de oficio, ni tan siquiera ser asistido de letrado. Como en los casos que venimos exponiendo en este apartado se acordó el sobreseimiento de las actuaciones judiciales y el Tribunal Constitucional volvió a inadmitir el recurso de amparo, desoyendo la doctrina jurisprudencial que derivaba de los recientes pronunciamientos del Tribunal de Estrasburgo. Como era de esperar este último recalcando la ausencia de una investigación oficial efectiva sobre los hechos alegados por el demandante, que permitiera la identificación de y en su caso castigo de los responsables; de suerte al que no tomar declaración por las autoridades jurisdiccionales españolas a los agentes que llevaron a cabo los interrogatorios durante el periodo de incomunicación, se vulneraba el artículo 3 del Convenio en su vertiente procesal.

${ }^{45}$ Entre las que destacamos: la persona detenida incomunicada tiene derecho a informar a una persona de su elección, de su detención y de su lugar, tan pronto como sea posible, y no más tarde de cuarenta y ocho horas tras la privación inicial de libertad; derecho a entrevistarse con un abogado en privado y ser reconocido por médico forense de su elección; prohibición expresa de vendar los ojos durante los interrogatorios o de que se les obligue a realizar ejercicios físicos o permanecer de pie de manera prolongada; necesidad de grabación en video de las detenciones incomunicadas: prohibición de aplicación de la detención incomunicada a los menores; obligación de comparecer sistemáticamente ante el Juez competente antes de que resuelva sobre la prórroga de la detención más allá de las setenta y dos horas, en los casos de personas sujetas a las prescripciones del artículo 520 bis de la Ley de Enjuiciamiento Criminal. 
A pesar de las observaciones formuladas por diferentes organismos internacionales y de la ya consolidada doctrina jurisprudencial que venimos exponiendo, parece que los órganos jurisdiccionales españoles se resisten a llevar a cabo la investigación profunda y efectiva que demanda el Tribunal de Estrasburgo en los casos de detención incomunicada. Así se refleja en el asunto Etxebarría Caballero, de fecha 7 de octubre de 2014, en el que se ha vuelto a condenar al Estado español por vulneración del artículo 3 del Convenio en su vertiente procesal ${ }^{46}$.

Entendemos que las diferentes resoluciones del TEDH revelan como inexplicablemente no se acometen por el Estado español las reformas legislativas necesarias que acomoden nuestro ordenamiento jurídico a la jurisprudencia del TEDH, toda vez que las reiteradas condenas a nuestro país por vulneración del artículo 3 del Convenio en su vertiente procesal, le sitúan en una situación de descrédito internacional en la protección y defensa de los derechos humanos, como miembro del Consejo de Europa. Así lo ha puesto de relieve Díaz $\mathrm{Crego}^{47}$ al afirmar que el legislador español no ha corregido ciertas deficiencias estructurales en nuestro ordenamiento, muy especialmente en lo que se refiere a la preceptiva investigación de denuncias por malos tratos relacionadas con la actuación de las Fuerzas y Cuerpos de seguridad. Mas no es menos cierto que «España acumula un escaso número de sentencias condenatorias relacionadas con la vulneración de los artículos 2 y $3 C E D H$ », como asevera la citada autora.

${ }^{46}$ Reiterándose que la ausencia de una investigación efectiva sobre los malos tratos y vejaciones denunciados por la demandante han impedido, «más allá de toda duda razonable» determinar la violación del artículo 3 en su manifestación sustantiva. Reprocha, a los órganos jurisdiccionales españoles, el Tribunal de Estrasburgo, dada la especial situación de vulnerabilidad en la que se encuentran las personas detenidas en régimen de incomunicación, la inobservancia de las medidas propuestas por los diferentes instancias internacionales (especialmente del $\mathrm{CPT}$ ), siendo aquéllos garantes de la integridad de la demandante durante dicho periodo y correspondiendo al Estado español dar una explicación satisfactoria y convincente sobre la ausencia de malos tratos durante el arresto y la detención incomunicada; produciéndose así una inversión de la carga de prueba que recae directamente en el Estado español.

${ }^{47}$ Díaz CRego, M. (2014). «La jurisprudencia del Tribunal Europeo de Derechos Humanos en torno a España: Una historia de encuentros y desencuentros», en García Roca, J y Santolaya Machetti, P. (coords.), La Europa de los Derechos: Convenio Europeo de Derechos Humanos, Madrid, Centro de Estudios Políticos y Constitucionales, págs. 791 a 831 . 


\section{Derecho a la libertad y la seguridad (art. 5 CEDH)}

Por su parte, Arriese Irondo ${ }^{48}$ mantiene que el derecho a la libertad consagrado en el artículo 5 ha de entenderse en sentido clásico, como libertad física, no incluyéndose otras libertades recogidas en el Convenio. Por otro lado, y a los efectos de determinar el ámbito de aplicación del precepto, distinguen, Álvarez García y Queralt Jiménez ${ }^{49}$, entre privación de libertad y restricciones de libertad de circulación previstas en el artículo 2 del Protocolo núm. 4.

En cuanto a las condiciones, aunque "no se requiere que se espose a la persona, sea encerrada en una celda o restringida físicamente de cualquier otra manera», sí es determinante "que una vez dentro del lugar de detención esté sometida a vigilancia constante y no sea libre para marcharse». Por otro lado, corresponderá a cada Estado signatario la determinación de los supuestos en que podrá producirse dicha privación de libertad, de modo que deberá practicarse de conformidad con los fines recogidos en el citado artículo, excluyéndose la arbitrariedad, «entendida ésta no como mera ilegalidad, sino como injusticia, imprevisibilidad, irracionalidad, capricho y desproporcionalidad». Ello no implica, aseveran Álvarez García y Queralt Jiménez ${ }^{50}$, que estemos en presencia de un derecho de configuración legal, sino que corresponde a las diferentes normas constitucionales y diversos instrumentos constitucionales, la determinación de las citadas condiciones.

Junto al derecho a la libertad se reconoce el derecho a la seguridad, aunque referido "única y exclusivamente a la prohibición de ataques arbitrarios contra el derecho a la libertad» ${ }^{51}$.

El contenido del artículo 5 también engloba la llamada «desaparición forzosa». A esta última se refiere la jurisprudencia el TEDH en diversas sentencias, recientes, recurriendo a la noción de «desaparición forzosa», acuñada por el derecho internacional, y que consiste en "la privación de libertad, la negativa a reconocer dicha privación o el ocultamiento de la suerte o el paradero de la persona desaparecida, sus-

${ }^{48}$ Así, ArRiese Irondo, M. ${ }^{\text {a }}$ N. (2015), «Artículo 5. Derecho a la libertad y a la seguridad», en Lagasabaster Herrarte I. (dir), Convenio Europeo de Derechos Humanos: Comentario sistemático, Madrid, Editorial Aranzadi S. A., págs. 113 a 202.

${ }^{49}$ Álvarez García, F. J. y Queralt JimÉNEZ, A. (2014). «El derecho a la libertad y a la seguridad y su sistema de garantías en el Convenio de Roma: un estándar mínimo europeo», en García Roca, J y Santolaya Machetti, P. (coords.), La Europa de los Derechos: Convenio Europeo de Derechos Humanos, Madrid, Centro de Estudios Políticos y Constitucionales, págs. 129 a 200.

50 Álvarez García, F. J. y Queralt Jiménez, A. (2014), op. cit., págs. 129 a 200.

${ }^{51}$ ArRese Iriondo, M. ${ }^{a}$ N.(2015), op. cit., págs. 113 a 202. 
trayéndola de la protección de la ley», tal y como se define en la Convención Internacional para la protección de todas las personas contra las desapariciones forzadas.

En lo que se refiere a la titularidad del derecho, hemos de predicarla de cualquier persona física, sin que pueda extenderse a las personas físicas. El TEDH lo extiende a las personas condenadas, aunque lo sean a cadena perpetua ${ }^{52}$.

En el asunto José Luis Mateos Sánchez c. España ${ }^{53}$ de fecha 16 de abril de 1996, el TEDH declaró inadmisible la demanda por no haberse agotado las vías de recurso interno.

Derecho a un proceso equitativo (art. $6 \mathrm{CEDH})$

A diferencia el derecho a la libertad, el derecho a un proceso equitativo no es un derecho absoluto, sino de configuración legal por cada Estado signatario, dentro de un amplio margen de discrecionalidad, que no podrá vulnerar el núcleo esencial de aquél. Suele distinguir$\mathrm{se}^{54}$ en el citado precepto dos partes diferenciadas, relativas a los principios del proceso equitativo (ya sea en el oren civil o penal) y a una serie de garantías a los inculpados en el proceso penal. De suerte que el artículo 6 garantiza «frente al Estado, un derecho subjetivo de cada ciudadano -nacional, extranjero, persona física, o con algún matiz, persona jurídica- al proceso debido $»^{55}$.

Nuestro país ha sido condenado en numerosas ocasiones por la vulneración del artículo 6 del Convenio, tanto en su vertiente del de-

${ }^{52}$ Asunto Weeks c. Reino Unido, de fecha 2 de marzo de 1987.

${ }^{53} \mathrm{El}$ demandante había sido condenado a una pena privativa de libertad de siete años por la comisión de un delito de homicidio con circunstancia eximente incompleta de enajenación mental siendo internado en un centro psiquiátrico. El demandante había solicitado su traslado a un centro penitenciario ordinario por mejoría en su estado de salud, a lo que se negó la Audiencia Provincial de Murcia. A mayor abundamiento el TEDH declaró expresamente que "los procesos relativos al internamiento de una persona en un centro psiquiátrico no afectan a los derechos y obligaciones de carácter civil ni al fundamento de una acusación en materia penal. Resulta que el proceso incriminado no depende el artículo 6.1 del Convenio».

${ }^{54}$ ARANGUENa Fanego, C. (2014). «Primera aproximación al Derecho a un proceso equitativo y a las exigencias contenidas en artículo 6.1 CEDH; en particular el derecho de acceso a un tribunal». García Roca, J y Santolaya Machetti, P. (coords.), La Europa de los Derechos: Convenio Europeo de Derechos Humanos, Madrid, Centro de Estudios Políticos y Constitucionales, págs. 201 a 228.

${ }^{55}$ Esparza Leibar, I. y EtXABERRía GuRIDI, J. F. (2015). «Artículo 6. Derecho a un proceso equitativo", en Lasagabaster Herrarte, I. (dir.). Convenio Europeo de Derechos Humanos: comentario sistemático, Madrid, Aranzadi, págs. 203 a 297. 
recho al debido proceso como a las dilaciones indebidas en procesos judiciales, constituyendo en nuestro "talón de Aquiles» ${ }^{56}$ en relación con la jurisprudencia del Tribunal de Estrasburgo.

En la Sentencia de fecha 22 de julio de 2008, en el caso Gómez de Liaño c. España se declaró la vulneración del derecho a un proceso justo, en su modalidad de derecho a un Tribunal imparcial, al apreciar que el órgano jurisdiccional encargado de juzgar al demandante suscitaba serias dudas sobre su imparcialidad, toda vez que todos sus miembros habían participado en la fase instrucción e incluso en la apelación contra el Auto de procesamiento dictado contra el demandante. En parecidos términos se pronuncia el TEDH en el asunto Cardona Serrat contra España, de fecha 26 de octubre de 2010, toda vez que el demandante fue condenado por la Audiencia Provincial de Valencia por un delito continuado de abusos sexuales. Dos de los tres magistrados que componían dicha Sala habían acordado previamente el ingreso en prisión del demandante, por lo que a juicio del TEDH tenían por tanto una idea preconcebida de su culpabilidad.

En el asunto Igual Coll c. España de fecha 10 de marzo de 2009, concluyó que se había vulnerado el artículo 6 del CEDH, en su vertiente de derecho a la defensa, por haberse condenado al demandante en apelación sin vista, tras haber sido absuelto en primera instancia.

Durante el año 2010 nuestro país fue objeto de dos sentencias condenatorias por vulneración del artículo 6, en su modalidad de derecho de defensa. La primera de ellas en el asunto Marcos Barrios c. España de fecha 21 de septiembre de 2010 por cuanto el demandante había sido absuelto en primera instancia y condenado en apelación como autor de un delito de asesinato sin que se celebrara vista. A la misma conclusión llega el TEDH en el asunto García Hernández c. España de fecha 16 de noviembre de 2010.

Más recientemente en el asunto Alony Kate c. España, de fecha 17 de enero de 2012, el Estado español fue objeto de una resolución condenatoria $^{57}$.

${ }^{56}$ Díaz Crego, M. (2014), op. cit., págs. 791 a 827.

${ }^{57}$ Esta vez por violación del derecho a un juicio justo, en su manifestación del derecho a un juez imparcial. Se trataba de un nacional español, aunque de origen sirio, que fue condenado por la Audiencia Nacional por un delito de colaboración con banda armada. El TEDH consideró que podía dudarse de la imparcialidad objetiva de los magistrados de la Audiencia Nacional que acordaron la prisión provisional del demandante, cuando el Juez de Instrucción le había concedido la libertad provisional. 
En ese mismo año en el asunto Serrano Contreras c. España, de fecha 20 de marzo de 2012, el TEDH trayendo a colación la doctrina ya sentada en la Sentencia Lacadena Calero de 22 de noviembre de 22 de noviembre de 2011, admitió que se había privado al demandante de su derecho de defensa, de suerte que el Tribunal Supremo le condenó con apoyo en una serie de informes resultantes de Comisiones Rogatorias, que convirtiéndose en determinantes de su culpabilidad sin que las partes tuvieran ocasión de examinarlo de acuerdo con los principios de inmediación y contradicción. No obstante, reprochó a España la demora de más once años en administrar justicia por los órganos jurisdiccionales españoles, que no se justificaba por la complejidad del caso (dos comisiones rogatorias); reconociendo al demandante su derecho a no sufrir dilaciones indebidas.

En el asunto Román Zurdo y otros c. España de fecha 8 de octubre de 2013, Nieto Macero c. España de igual fecha y Sainz Casla de fecha 12 de noviembre de 2013 se dictaron resoluciones condenatorias contra nuestro país por vulneración del artículo 6 del CEDH, en concreto por haber sido condenados en segunda instancia por la jurisdicción interna sin ser oídos personalmente.

Posteriormente en el asunto Varela Geis c. España de 5 de marzo de 2013, estimó el Tribunal de Estrasburgo que se había producido una vulneración del derecho a un proceso equitativo, en su vertiente a ser oído y asistido legalmente ${ }^{58}$.

A sensu contrario, en el asunto Gani c. España, de fecha 19 de febrero de 2013, se determinó por el TEDH que no se había producido vulneración del artículo 6 del CEDH por haberse admitido, por el Tribunal de apelación, como prueba las declaraciones efectuadas por el acusado durante las diligencias preliminares. Tampoco se dictó sentencia condenatoria contra nuestro país en el asunto Naranjo Acevedo de fecha 22 de octubre de 2013, por apreciarse que se respetaron las garantías procesales en segunda instancia del «demandante» condenado por un delito de robo con violencia, uso de armas de fuego y asesinato.

En cambio, no apreció violación del artículo 6 apartados 1,2,3 del Convenio en el asunto Vaquero Hernández y otros c. España de fecha 2 de noviembre de 2010. Delimitando su propia competencia el Tribunal de Estrasburgo manifestó que no le corresponde reinterpretar los elementos de prueba que han servido para dictar condena, ni reexaminar

${ }^{58}$ Dado que se habría impedido al «demandante» la preparación adecuada de su defensa, alegando este que había sido condenado en apelación por la Audiencia Provincial de Barcelona por un delito de genocidio, que no figuraba en el escrito de acusación y por el que no había sido condenado en primera instancia. 
las pruebas, aunque si le incumbe «asegurarse de que los medios de prueba han sido practicados para garantizar un proceso justo»; estando vedado al TEDH por tanto «sustituir con su propia apreciación de los hechos y de las pruebas, la de las jurisdicciones internas».

Derecho a la vida privada, vida familiar y al secreto de la correspondencia (art. $8 \mathrm{CEDH})$

No encontró el TEDH, en el asunto Abdulkadir Coban c. España de fecha 26 de septiembre de 2006, vulneración del derecho al secreto de las comunicaciones del «demandante», en concreto de las telefónicas, que habían sido interceptadas en el marco de un proceso penal por un delito de tráfico de drogas, por entender aquél que se trata de una injerencia prevista en la legislación española y en su jurisprudencia de forma clara y detallada, motivada adecuada y suficientemente en un Auto y sometida a control judicial. En esta Sentencia el TEDH trae a colación la doctrina fijada en el asunto Prado Bugallo c. España de fecha 18 de febrero de 2003, en la que se recogía de forma palmaria que las modificaciones introducidas en el artículo 579 de la Ley de Enjuiciamiento Criminal por la L. O. 4/ 1988, de 25 de marzo de 1988 no respondían a las condiciones ${ }^{59}$ exigidas por el TEDH en esta materia; si bien es cierto que este último reconoce la labor integradora llevada a cabo por la jurisprudencia del Tribunal Supremo, especialmente a partir del Auto de 18 de junio 1992, y por la del Tribunal Constitucional ${ }^{60}$.

En síntesis puede concluirse con Díaz $\mathrm{Crego}^{61}$ que nuestro país no es de los países signatarios del Convenio con un mayor número de demandas y sentencias condenatorias, a pesar de las deficiencias estructurales apreciadas por el TEDH, muy particularmente en lo que se refiere a «vulneraciones de las garantías asociadas al debido proceso, la obligación de investigar eventuales denuncias de malos tratos y del principio de legalidad, al hilo de la aplicación de la doctrina Parot».

\section{Demandas individuales (art. $34 \mathrm{CEDH})$}

Recientemente el TEDH ha entendido, en el asunto Cano Moya c. España, de fecha 11 de octubre de 2016, que se vulneraba por estado

${ }^{59}$ Existencia de una injerencia prevista por la ley (con base legal en derecho interno) finalidad y necesidad de la injerencia en una sociedad democrática.

${ }^{60}$ Por todas, STC 184/2003 de 23 de octubre de 2003.

${ }^{61}$ Díaz Crego, M. (2014) op. cit., págs. 791 a 827. 
español (un derecho de naturaleza procesal, no sustantivo) el artículo 34 del convenio al obstaculizar a un recluso, que había sido objeto de una sanción disciplinaria, el derecho a presentar una demanda ante aquél, toda vez que el Juzgado de Vigilancia penitenciaria le denegaba copia de su expediente penitenciario. Asimismo, le fue denegado el acceso en amparo ante el TC por carecer la demanda de trascendencia constitucional. Si bien el TEDH declaró que la obligación de no entorpecer el derecho a una demanda individual no significa automáticamente que el Estado tiene el deber de proporcionar los demandantes una copia de la documentación, el Tribunal también ha establecido que el artículo 34 del Convenio puede imponer a las autoridades estatales la obligación de facilitar copia de documentación a aquellos demandantes que se hallen en situaciones de especial vulnerabilidad o dependencia e incapaces de obtener la documentación necesaria sin ayuda del Estado».

\subsection{Excursus sobre la doctrina «Parot»}

Llama poderosamente la atención de la redacción del artículo 7 del Convenio el que se considere fuente del Derecho Penal la jurisprudencia, la costumbre y los principios generales del Derecho reconocidos por las naciones civilizadas; lo que ha llevado a la doctrina penalista patria a subrayar «el contenido debilitado el principio europeo de legalidad ${ }^{62}$, incurriendo tal precepto en un cierto "déficit democrático», abriendo la puerta a la imposición de penas en virtud de normas que no ostentan el rango formal de ley, $y$ desembocando en «un Derecho penal de la Unión Europea sustitutivo.....de los Derechos penales nacionales». Estamos pues en presencia de la no exigencia, por el artículo 7, de reserva absoluta de ley en materia penal, lo que conlleva de forma ineludible enormes problemas a la hora de conectar «los preceptos constitucionales propios de cada país con la interpretación que ha merecido dicha cláusula por el TEDH».

En ese orden de cosas hemos de destacar que el Convenio, en su artículo 7, tampoco acoge expressis verbis el principio de retroactividad de la ley penal más favorable. Por el contrario, sí que se deduce de la jurisprudencia del TEDH la prohibición de la analogía in malam partem.

${ }^{62}$ Huerta Tocildo, S. (2014). «El contenido debilitado del principio europeo de legalidad penal. Art. 7 CEDH y art. 4 y P7», en García Roca, J. y Santolaya Machetti, P. (coords.), La Europa de los Derechos: Convenio Europeo de Derechos Humanos, Madrid, Centro de Estudios Políticos y Constitucionales. 
En relación con el derecho reconocido en el artículo $7 \mathrm{CEDH}$, nuestro país ha sido condenado en tres ocasiones, destacando el asunto Del Río Prada c. España de fecha 10 de julio de 2012, en el que TEDH constató la violación de los artículos 5 y 7 del Convenio. La demandante fue condenada por la Audiencia Nacional por la comisión de los delitos de pertenencia a organización terrorista, posesión ilícita de armas y explosivos, atentados, lesiones, asesinatos y tentativas de asesinatos, estragos, a un total de más de tres mil años de penas privativas de libertad, si bien de conformidad con el artículo del 70.2 del Código penal de 1973 el tiempo máximo de cumplimiento efectivo era de treinta años. Hasta la fecha una consolidada jurisprudencia del Tribunal Supremo venía estableciendo que los beneficios penitenciarios recogidos en la normativa penal y penitenciaria se aplicaban sobre la pena máxima de cumplimiento efectivo. De forma sorpresiva la doctrina jurisprudencial fijada se modificó por el Tribunal Supremo en su Sentencia de 197/2006, de 28 de febrero en la que sostenía ahora que las remisiones de penas debían aplicarse sobre cada una de las penas impuestas de manera individual y no sobre el máximo de treinta años de cumplimiento; por lo que vendría obligada la demandante a cumplir íntegramente el plazo de treinta años de pena privativa de libertad. A tal efecto el Centro penitenciario en el que se hallaba recluida la demandante, teniendo en cuenta que había ingresado en prisión el día 14 de febrero de 1989, determinó que correspondía su puesta en libertad el 2 de julio de 2008, a lo que la Audiencia Nacional replicó que debía procederse a un nuevo cómputo de conformidad con la nueva doctrina del Tribunal Supremo, la conocida como doctrina Parot. La nueva fecha resultante sería pues el 27 de julio 2017, fijada por Auto de la Audiencia Nacional. Tanto el posterior recurso de súplica ante el citado órgano jurisdiccional como el recurso de amparo ante nuestro Tribunal Constitucional fueron desestimado el primero e inadmitido el segundo, por cuanto la demandante no había justificado la pertinencia constitucional de sus denuncias.

El TEDH a través de su Sección Segunda consideró que se vulneraba el derecho a la libertad y seguridad de la demandante, por cuanto ésta no podía en el momento de acumulación de todas sus penas «que el método de cálculo de estas redenciones de condena serían objeto de un giro jurisprudencial del Tribunal Supremo en 2006 y que este cambio se le aplicaría retroactivamente». Asimismo, el TEDH reprocha a nuestro Estado que el principio de legalidad de los delitos y las penas que proclama el artículo 7 del Convenio prohíbe que el Código Penal pueda ser interpretado en perjuicio del reo, sin detrimento de que los Estados 
puedan modificar su política penal, reforzando la represión de los crímenes y delitos. A mayor abundamiento «la aplicación con efecto retroactivo de las Leyes penales posteriores solo se admite cuando el cambio legislativo es favorable al acusado", recordando la doctrina establecida en el asunto Scoppola c. Italia de fecha 17 de septiembre de 2009. Por otro lado el Tribunal de Estrasburgo constató que el cambio jurisprudencial operado en el año 2006 por el Tribunal Supremo tuvo lugar una vez entrado en vigor el vigente Código penal de 1995. En última instancia el propio TEDH concluyo que es responsabilidad del Estado español la puesta en libertad de la demandante en el menor tiempo posible. El Gobierno español recurrió la Sentencia ante la Gran Sala al amparo de los artículos 43 y 44 del Convenio. Ni que decir tiene que fue confirmada por esta última, en Sentencia de 21 de octubre de 2013.

Mas al margen de cuestiones netamente procesales, Gimeno Sendra $^{63}$ pone de relieve como el TEDH en la sentencia objeto de este apartado, ha «creado un nuevo derecho fundamental en nuestro ordenamiento, cual es el que asiste a todo recluso a no ver incrementada su condena por encima de la pena prevista en el momento en que hubiera cometido la infracción», al incluirse por el Tribunal de Estrasburgo en el contenido del principio de legalidad (artículo 7) no solo el principio de tipicidad, sino el de "penalidad»(art. 7.1 in fine); lo que conllevará, en palabras del citado autor, a una "petrificación de la doctrina legal del TS», ya que no podrá modificarla in peius, sin incurrir en «infracción del principio de legalidad en su manifestación de previsión de la penalidad». Concluye Gimeno Sendra que el propio TEDH incurre en error al identificar derecho legislado con jurisprudencia, toda vez que «respecto a la jurisprudencia no rige la prohibición de retroactividad».

\subsection{Análisis de la jurisprudencia del TEDH sobre reclusos no relativa a España}

A semejanza del análisis efectuado de las resoluciones del TEDH en las que resulte afectado nuestro país, procede ahora la exégesis de aquellas resoluciones dictadas en asuntos en los que no viéndose demandada España, contribuyen a delimitar el contenido esencial y límites de los derechos de los reclusos. Para ello nos detendremos en los derechos invocados por los demandantes privados de libertad, en sentido amplio del término.

${ }^{63}$ Gimeno SEndRa, V. (2014), op. cit., págs. 1 a 10; en la que recuerda que «desde el tenor literal del artículo 25.1 CE y desde la jurisprudencia del TC, el principio de legalidad ha venido siendo exclusivamente concebido como principio de tipicidad». 
Prohibición de la tortura y de tratos y penas inhumanos y degradantes (art. $3 \mathrm{CEDH})$

El artículo 3 del Convenio contempla como actuaciones que deben ser erradicadas de los Estados Parte tanto la tortura como los tratos inhumanos y degradantes. Será preciso deslindar ambas nociones a la luz de la jurisprudencia del TEDH. El trato inhumano ${ }^{64}$ requiere haber sido "aplicado con premeditación durante horas, causando bien lesiones corporales bien graves sufrimientos psíquicos y mentales» ${ }^{65}$. Por su parte trato degradante ${ }^{66}$ es "aquel que provoca sentimientos de miedo, angustia e inferioridad orientados a humillar, degradar y quebrantar eventualmente la resistencia física o moral de la persona a quienes se le aplican, o a obligarla a actuar en contra de su voluntad o su consciencia.»

En ese orden de cosas entiende el Tribunal que para calificar jurídicamente una conducta como tortura debe concurrir un mayor nivel de crueldad, de gravedad y un elemento intencional: una voluntad deliberada (especial vileza de tratos inhumanos deliberados que provocan sufrimientos muy graves y crueles ${ }^{67}$ Sin embargo amenazar a alguien con torturarle puede constituir cuando menos un trato inhumano y no una tortura en sentido estricto, a pesar de que haya organizaciones internacionales (v. gr. Redress Trust) que califiquen una amenaza de tortura como tortura, comprendiendo ésta los padecimientos físicos y mentales: «el temor a la tortura física puede constituir en sí misma una tortura mental».

De suerte que el TEDH establece como doctrina reiterada la nítida diferenciación entre la vertiente ${ }^{68}$ procesal y material del artículo 3 del Convenio. Los requisitos para que tenga lugar la primera de ellas (vertiente procesal) serían: la ausencia de una investigación oficial efectiva, que permita una perfecta identificación de los autores de los hechos constitutivos de tortura o de tratos inhumanos o degradantes (asunto Corsacov contra Moldavia de fecha 4 abril de 2006, y asunto Assenov y otros c. Bulgaria de fecha 28 de octubre de 1998); además de efectiva debe producirse una investigación rápida y exhaustiva,

${ }^{64}$ Calificándose como tal en la STEDH de fecha 27 de noviembre de 2003, asunto Henaf c. Francia, el hecho de atar a un preso la noche de ser trasladado a un hospital extrapenitenciario para ser intervenido.

${ }^{65}$ Vid. STEDH de fecha 1 de junio de 2010, asunto Gafgen c. Alemania.

${ }^{66}$ A modo de ejemplo, el TEDH consideró, en el asunto Yankov c. Bulgaria, de 11 de diciembre de 2003, como trato degradante rapar la cabeza de un recluso.

${ }^{67}$ Asunto Askoy c. Turquía SSTEDH de fecha 18 de diciembre de 1996.

${ }^{68}$ Asunto "El Masri c. Ex República Yugoslava de Macedonia», de fecha 13 de diciembre de 2012. 
debiéndose adoptar todas las medidas a su alcance por las autoridades para recabar pruebas sobre los hechos, incluidas las declaraciones de testigos y las pruebas forenses (asunto Gul c. Turquía de fecha 14 de diciembre de 2000); la investigación debe practicarse en tercer lugar con total independencia del poder ejecutivo (asunto Mehmet Emin Yuksel c. Turquía de 20 de julio de 2004) y contar con la participación efectiva de la víctima en aquélla (asunto Ognyanova y Choban contra Bulgaria de fecha 23 de febrero de 2006, Denis Vasilev contra Rusia de 17 de diciembre de 2009, Khadjaliyev c. Rusia de 6 de noviembre de 2008).

En lo que se refiere al esclarecimiento de los hechos que puedan ser constitutivos de las conductas prohibidas por el artículo 3, han de ser objeto de un "examen particularmente exhaustivo" (asunto Ribitsch c. Austria de fecha 4 de diciembre de 1995 y Georgiy Bykov contra Rusia de 14 de octubre de 2010).

Por otro lado será necesario para la vulneración del artículo 3 del Convenio en su vertiente material que los malos tratos alcancen un mínimo de gravedad, para lo que habrá de atenderse a una serie de variables, como la duración del trato y de sus efectos físicos y mentales y en ocasiones, el sexo, la edad de la víctima, y su estado de salud (asunto Irlanda contra Reino Unido de 18 de enero de 1978), el propósito con el que se infligió el maltrato y la intención o motivación que lo inspiraron ( Krastanov contra Bulgaria de 30 de septiembre de 2004).

Común a ambas conductas proscritas sería la advertencia que efectúa el Tribunal cuando determina que la torturas o tratos inhumanos o degradantes no están justificados ni siquiera cuando la vida de un individuo está en peligro, ni en el caso de amenaza pública hacia la vida de la nación, y ello con independencia de las actuaciones de la persona sometida a tales actos o de la motivación de las Autoridades. Constituye pues en la redacción del artículo 3 del CEDH y en su aplicación e interpretación por el TEDH un derecho absoluto e inalienable reconocido a toda persona y que no admite excepciones al amparo del artículo 15.2 del Convenio (a diferencia de la mayoría de las cláusulas del mismo), por cuanto constituye «uno de los valores fundamentales de las sociedades democráticas «. No siendo admisible su utilización por los Estados parte para combatir el terrorismo o el crimen organizado.

Sin embargo en el asunto A. y otros c Reino Unido, de 19 de febrero de 2009, el TEDH declaro no haber lugar a la violación del artículo 3 del CEDH, por entender que los demandantes recluidos en diversas 
prisiones y hospitales psiquiátricos británicos, gozaban según el derecho interno del país anglosajón " «de la posibilidad de revisar la pena perpetua con el fin de conmutarla, suspenderla, o concluirla o incluso poner en libertad condicional al preso", toda vez que «infligir a un adulto una pena perpetua e incomprensible de reclusión que excluya toda esperanza de puesta en libertad " podría constituir una vulneración del artículo 3 del Convenio. Y ello a pesar de que el Comité Europeo para la Prevención de la Tortura y de las Penas o Tratos Inhumanos o Degradantes, como consecuencia de sendas visitas efectuadas, señaló que el estado de salud de la mayor parte de los presos (demandantes) había empeorado por la reclusión, en particular, a causa del carácter indeterminado de su duración. Es más, calificó la situación de los presos «como trato inhumano y degradante».

Esta línea jurisprudencial ha sido mantenida en sentencias posteriores como la recaída en el asunto Vinter y otros contra Reino Unido, de fecha 9 de julio de 2013, al afirmarse de forma tajante «que para que una cadena perpetua resulte compatible con el artículo 3 del convenio, deben existir tanto la expectativa de ser puesto en libertad como la posibilidad de revisión de la pena.». Pero no es menos cierto que el que caen fuera del ámbito competencial del TEDH la elección del sistema penal concreto, los mecanismos de revisión de las penas y las condiciones de la puesta en libertad, recayendo pues en los Estados Parte del Convenio la adecuada duración de las penas privativas de libertad, incluyendo la cadena perpetua, así como las condiciones de aquéllas.

A juicio del Tribunal asimismo se lesionaría el derecho a la integridad física y moral del demandante, esto es, la vulneración del artículo 3 del Convenio, en aquellos casos en los que el cumplimiento de una orden de extradición ${ }^{69}$ de un recluso, lo coloque en una situación de riesgo real e inminente de sufrir malos tratos. Para ello se exige en la jurisprudencia del TEDH una seria de requisitos acumulativos: Debe valorarse por el Tribunal las condiciones del país de destino que sean contrarias las normas del CEDH, es decir, si existen razones fundadas para creer que el individuo extraditado se le expondría a un riesgo real e inminente de ser sometido a tratos inhumanos (asunto Saadic. Italia y Soering c. Reino Unido de fecha 7 de julio de 1989); en segundo lugar comprobar si las autoridades del país donde se encuentra el demandante sobre el que recae la petición de extradición cumplieron la obligación positiva de proteger a este del riesgo real e inmediato por el traslado forzoso al país de destino; y en última instancia si a la extradición ha seguido una investigación rápida y efectiva sobre la

${ }^{69}$ STEDH de 25 de abril de 2013, asunto Savriddin Dzhurayev c Rusia. 
reclamación de tortura o malos tratos por agentes del Estado (asunto Assenov y otros c. Bulgaria de fecha 28 de octubre de 1998, asunto Gul c. Turquía de fecha 14 de diciembre de 2000).

En todos los supuestos de acusaciones por los demandantes de vulneración del artículo 3 el Convenio, el TEDH exige un «examen particularmente exhaustivo ${ }^{70}$, de los hechos de los que deriva la demanda, incluyéndose «la calidad del procedimiento interno y cualquier deficiencia que vicie el proceso interno" ${ }^{71}$; aunque como corolario de dicha tesis condiciona la vulneración del artículo 3, en su vertiente material, del CEDH a aquellos casos en los que se hayan acreditado por el demandante las acusaciones «más allá de toda duda razonable» ${ }^{72}$.

Singularmente pone de relieve López Ulla ${ }^{73}$, que en el asunto Ramihi c. Grecia, de fecha 5 de abril de 2011, el TEDH realiza del artículo 3 una «interpretación abierta y finalista que para su adaptación a la realidad de los tiempos el Convenio demanda», al entender que se vulnera dicho precepto, en su vertiente material, por las autoridades helenas no solo por las condiciones infrahumanas del internamiento, una vez producida la detención de un menor no acompañado de origen iraní, sino que, por primera vez se afirma que la situación de desamparo en la que queda el menor una vez decretada su expulsión del país, sin la más mínima asistencia, constituye asimismo conculcación del citado precepto.

Derecho a la libertad y la seguridad (art. 5 CEDH)

El derecho a la libertad y a la seguridad, en palabras del TEDH (asunto Askoy c. Turquía de fecha 18 de diciembre de 1996), consagra un derecho fundamental consistente en la protección de toda persona frente a violaciones arbitrarias del Estado a su libertad. Debe tenerse presente que la lista de excepciones recogidas en el mismo tiene naturaleza de numerus clausus, debiendo ser objeto de una interpretación estricta (asunto Asatryan c. Armenia de fecha 9 de febrero de 2010).

De modo recurrente viene distinguiéndose en la jurisprudencia del TEDH entre vulneración en sentido material y formal del derecho a la

${ }^{70}$ Asunto Georgiy Bykov c. Rusia de 14 de octubre de 2010.

${ }^{71}$ Asunto Denisenko Bogdanchickov c. Rusia de 12 de febrero de 2009.

${ }^{72}$ Así se establece en SSTEDH de fecha 13 de diciembre de 2012 ap. 167, asunto El-Masri c. Ex-República Yugoslava de Macedonia.

${ }^{73}$ López Ulla, J. M. (2013). «Alcance del artículo 3 del Convenio Europeo de Derechos Humanos en relación con la detención de un menor extranjero no acompañado: la obligación positiva de no dejarle en desamparo». Teoría y Realidad Constitucional, núm. 32, págs. 481 a 497. 
libertad y a la seguridad, tal y como lo viene haciendo en relación con artículo 3 del $\mathrm{CEDH}^{74}$.

Entendemos acertada, en aras de lograr una mayor protección de las personas que se encuentran en una situación de especial vulnerabilidad, la inversión de la carga de la prueba que efectúa el TEDH en numerosos pronunciamientos ${ }^{75}$ al hacer recaer sobre las autoridades del Estado Parte demandado la presunción de que cualquier lesión o fallecimiento sufrido por una persona detenida o custodiada por aquéllas podrá serle atribuida como violación de los artículos 3 y 5 del convenio. De suerte que en ese afán proteccionista llega a afirmar el TEDH que un detención puede ser lícita según el ordenamiento jurídico de un Estado Parte y al mismo tiempo ser calificada de arbitraria, y por tanto contravenir el artículo 5 del Convenio, por no ser aplicada de buena fe, por no ser adecuados el lugar y condiciones de la detención, o por superar el plazo que sea necesario para lograr el fin perseguido ${ }^{76}$. Este criterio ha sido mantenido en la reciente sentencia de fecha 25 de abril de 2013, asunto Savriddin Dzhurayev c. $R u s i a$, en particular el apartado 4 del artículo 5 por las dilaciones indebidas sufridas por el demandante en la resolución de los recursos planteados durante su detención y posterior internamiento.

\section{Derecho a un proceso equitativo (art. $6 \mathrm{CEDH})$}

Amén de ser la «disposición convencional más invocada y que cuenta con mayor número de asuntos resueltos ante el Tribunal de Estrasburgo", a juicio del profesor Jimena Quesada ${ }^{77}$ el contenido esencial del dere-

${ }^{74}$ Así las cosas, consideró como detención arbitraria, el cautiverio, en régimen de aislamiento sufrido por el demandante en el asunto «El-Masri c. Ex República Yugoslava de Macedonia ", ignorándose su paradero durante más de cuatro meses. A tal efecto no se produjo una investigación por las autoridades el país (Macedonia) que disipara cualquier duda sobre las acusaciones del demandante de haber sufrido una desaparición forzosa, de suerte que el TEDH entendió conculcado el derecho a la libertad consagrado en el artículo 5 del Convenio en su vertiente procesal.

${ }^{75}$ Asunto Rupa c. Rumania de fecha 16 de diciembre de 2008, asunto Orhan c. Turquía de fecha 18 de junio de 2002, y de forma contundente en el asunto El -Masri c. Ex-República Yugoslava de Macedonia, ap. 152.

${ }^{76}$ Asunto A. y otros c. Reino Unido de 19 de febrero de 2009, apartado 162.

${ }^{77}$ JiMENA QUESADA, L. (2005), «El derecho a un proceso equitativo reconocido en el Convenio Europeo de Derechos Humanos y su proyección nacional: entre el tiempo para conocer Europa y el tiempo para hacer justicia conforme a los parámetros europeos». Cuadernos constitucionales de la Cátedra Fadrique Furiol Ceriol, núm. 50/51, págs. 177 a 191. En el citado trabajo se recalca, en aras de aumentar la efectividad del CEDH, la imprescindible formación en Derecho Europeo de los operadores jurídicos, incluyendo a los propios órganos jurisdiccionales. 
cho a un proceso equitativo puede descomponerse en tres manifestaciones: en el acceso a la jurisdicción, en la necesidad de una resolución judicial fundada en derecho y en la garantía de la ejecución de la decisión adoptada; subrayándose la trascendencia del factor temporal a la hora de configurar las legislaciones internas los diferentes plazos de acceso a la jurisdicción y para entablar recursos. Aun cuando la redacción literal del artículo 6 del Convenio parece referirse a los procesos civiles y criminales, merced al "papel instrumental o garantía transver$s l^{78}$ de los demás derechos fundamentales», puede extenderse, en virtud de una interpretación sistemática de aquél, a otros órdenes jurisdiccionales como el contencioso administrativo, militar, o social.

Como nos recuerda Gómez de Liaño Fonseca-Herrero ${ }^{79}$, el TEDH reconoce por primera vez en la Sentencia de 21 de febrero de 1975, asunto Golder c. Reino Unido, la necesidad de proteger el derecho de acceso a los Tribunales, aunque lo hace con arreglo a las garantías del derecho a un proceso equitativo, asimismo llamado «derecho a un tribunal».

El derecho recogido en el artículo 6 ha sido abordado por el Tribunal de Estrasburgo con ocasión del asunto Soering c. Reino Unido de 7 de julio de 1989. Recordando dicha jurisprudencia establece de nuevo en la SSTEDH de fecha 17 de enero de 2012, asunto Othman (Abu Qatada) c. Reino Unido, que «una decisión de expulsión o extradición, excepcionalmente, plantear una cuestión desde la perspectiva el artículo 6 cuando el fugitivo haya sufrido, tenga el riesgo de sufrir, una manifiesta denegación de justicia en el Estado demandante». A título ejemplificativo, y sin animo exhaustivo, se señala que estaremos en presencia de una denegación manifiesta de justicia en los supuestos de detención sin quepa la posibilidad de ser examinada por Tribunal independiente, la imposibilidad de que el detenido mantenga comunicación con su abogado, juicio sumario con inobservancia absoluta del derecho de defensa, sentencia condenatoria sin posibilidad de una revisión sobre el fondo de la acusación y por supuesto la obtención de pruebas incriminatorias mediante el uso de la tortura ${ }^{80}$.

78 JiMENA QuESADA, L. (2005), op. cit., pág. 186.

${ }^{79}$ Gómez de Liaño Fonseca-Herrero, M. (2006). «Los Derechos de naturaleza procesal en la Unión Europea: Protección y contenido». Revista de Derecho de la Unión Europea, núm. 11, 2. ${ }^{\circ}$ semestre, págs. 61 a 78.

${ }^{80}$ Utilizando por ejemplo la técnica de la «falaka o falanga «, consistente en infligir golpes en los pies como se reconoció por el Tribunal en el asunto Mammadov c. Azerbaiyán de 11 de enero de 2007, y en el asunto Valeriu y Nicolae Rosça c. Moldavia de fecha 20 de octubre de 2009 , entre otros. 
En el ámbito estrictamente penitenciario, en el asunto Bifulco c. Italia de fecha 8 de febrero de 2005, el TEDH declaró vulnerado el artículo 6 ( en su vertiente de plazo razonable o dilaciones indebidas) por la tardanza de un Tribunal de Vigilancia Penitenciaria a la hora de resolver un recurso interpuesto por un recluso en régimen de prisión especial, toda vez que afecta a los derechos del preso y a la validez limitada en el tiempo de la decisión recurrida ${ }^{81}$.

No hay pena sin ley (art. 7 CEDH)

La posición del TEDH sobre este precepto de capital importancia para cualquier persona privada de libertad, queda recogida en los pronunciamientos de fecha 17 de mayo de 2010, asunto Kokonov contra Letonia, y de 18 de julio de 2013, asunto Mastouf Damjanovic c Bosnia y Herzegovina. Es precisamente en esta última sentencia en la que el TEDH, reiterando su doctrina ya establecida en la primera resolución citada, califica este precepto como elemento central del Estado de Derecho y un instrumento esencial en la protección jurisdiccional de los derechos plasmados en el Convenio; subrayando su preeminencia en el hecho de que no sea posible su derogación ni siquiera en los casos de guerra u otro peligro público de conformidad con el artículo 15. En palabras del propio Tribunal se convierte así el articulo 7 en «una garantía efectiva contra las persecuciones, condenas y penas arbitrarias ${ }^{82}$ : declarando haber lugar a la violación del principios de legalidad de los delitos y de las penas (nullum crimen, nulla poena sine lege) y de irretroactividad de la ley penal menos favorable para el reo, contenidos en el artículo 7 del Convenio, como consecuencia de la aplicación retroactiva por los Tribunales de Justicia de Bosnia-Herzegovina de los preceptos contenidos en el Código Penal de 2003 (de Bosnia), por hechos delictivos cometidos por los demandantes en los años 1992 a 1995 ( crímenes de guerra) en lugar el Código penal de la antigua República Federal Socialista de Yugoslavia de 1976, que contenía penas más favorables a los reos.

Derecho a la vida privada, vida familiar y al secreto de la correspondencia (art $8 \mathrm{CEDH})$

El artículo 8 del Convenio reconoce a «toda persona» el derecho a que sea respetada su vida privada y familiar. Ante esta garantía nor-

\footnotetext{
${ }^{81}$ EsParza LeIBAR y EtXebarRía GuRIDI, J. F.(2015), op. cit., págs. 203 a 297.

${ }^{82}$ Asunto Mastouf Damjanovic c. Bosnia y Herzegovina.
} 
mativa debemos platearnos la cuestión de si, a juicio del TEDH, es aplicable a las personas privadas de libertad en virtud de condena penal. La respuesta puede encontrarse en la STEDH de fecha 13 de diciembre de 2012, asunto "El-Masri c. ex República Yugoeslava de Macedonia ${ }^{83}$, al afirmarse de forma tajante que tal precepto es extensible a "situaciones de privación de libertad» ${ }^{84}$, integrándose en el contenido esencial de tal derecho tanto la integridad física y moral de la persona, debiendo ser protegido de cualquier injerencia arbitraria de los poderes públicos ${ }^{85}$.

Dado que los presos gozan «de todos los derechos reconocidos por el Convenio, a excepción del derecho a libertad", forma parte del contenido esencial del derecho reconocido en el artículo 8, el contacto con su familia más cercana ${ }^{86}$. "La posición favorable del Tribunal al derecho de los presos a acceder a procedimientos de inseminación artificial, contrasta con su reluctancia a interpretar que el Convenio obligue a los Estados contratantes a establecer el derecho a gozar de visitas conyugales en prisión ${ }^{87}$, al tratarse de una cuestión de la que disfrutan de un amplio margen de apreciación por aquéllos, en función de sus recursos.

A mayor abundamiento el TEDH ha considerado contrario al Convenio la interceptación de las comunicaciones ya sean telefónicas, postales... entre los abogados y los reclusos, salvo que se acredite que el letrado actuara como partícipe junto al procesado en los hechos delictivos, en los asuntos Campbell c. Reino Unido de fecha 25 de marzo de 1992, Radkov c. Bulgaria, de 22 de abril de 2010, asunto Kopp c. Suiza de 25 de marzo de 1998 y en el asunto Scoto contra Suiza de fecha 28 de noviembre de 1991 (escucha de las entrevistas en prisión), y más recientemente en el asunto Pruteanu c. Rumania de fecha 3 de febrero de 2015.

${ }^{83}$ En la citada sentencia el Tribunal entendió que había sido conculcado el derecho del demandante garantizado en el artículo 8 del Convenio, toda vez que durante su privación de libertad durante cuatro meses (en régimen de aislamiento, sin ningún contacto con su familia, que ignoraba su paradero) se produjeron efectos devastadores en su integridad física y psicológica; de suerte que dicha injerencia en su vida privada y familiar «no estaba prevista por la ley».

${ }^{84}$ Asunto Raninen contra Finlandia de fecha 16 de diciembre de 1997.

${ }^{85}$ Asunto Kroon y otros contra Países Bajos.

${ }^{86}$ Así lo reconoció en el asunto Messina c. Italia, de fecha 28 de septiembre de 2000, tal y como se manifiesta por Arzoz Santiesteban, X. (2015). «Artículo 8. Derecho al respeto a la vida privada y familiar», en Lagasabaster Herrarte I. (dir.), Convenio Europeo de Derechos Humanos: comentario sistemático, Madrid, Aranzadi, págs. 338 a 438.

${ }^{87}$ Arzoz Santiesteban, X. (2015), op. cit., págs. 338 a 438. (Asunto Dickson c. Reino Unido de fecha 4 de diciembre de 2007). 


\section{Derecho a contraer matrimonio (art. $12 \mathrm{CEDH})$}

El precepto ${ }^{88}$ engloba dos derechos autónomos, como son el derecho a contraer matrimonio y a tener hijos ( $f u n d a r$ una familia), no exigiéndose por el TEDH como conditio sine qua non la convivencia entre los contrayentes para poder ejercer el primero de ellos ${ }^{89}$, especialmente en el caso de los reclusos como consecuencia del principio de separación de sexos. Como ha mantenido el Tribunal de Estrasburgo $^{90}$ no puede negarse este derecho por el status de condenado a penas privativas de libertad; no pudiendo impedirse por los Estados signatarios el ejercicio a los reclusos del derecho a casarse, salvo en los casos en los que exista obstáculo legal relativo al estado civil ${ }^{91}$ «según las leyes nacionales».

\section{Derecho a un recurso efectivo (art. 13 CEDH)}

Se ha afirmado que el derecho a un recurso efectivo «más que un derecho, en realidad es una garantía de los demás derechos reconocidos en el Convenio ${ }^{92}$. A juicio de Carmona Cuenca deben considerarse como requisitos del recurso efectivo: a) La instancia nacional que debe conocer el recurso no ha de ser necesariamente judicial, salvo excepciones relacionadas con el derecho a no sufrir malos tratos; b) la efectividad de un recurso no depende de la certeza de un resultado favorable; c) El artículo 13 no exige que exista un recurso interno contra las leyes, pero sí contra las normas reglamentarias; d) al menos en relación con ciertos derechos, el artículo 13 exige un recurso que pueda resolverse en un plazo útil para evitar la vulneración; e) el artículo 13 exige que el

88 "A partir de la edad núbil, el hombre y la mujer tienen derecho a casarse y a fundar a una familia según las leyes nacionales que rijan el ejercicio de este derecho».

${ }^{89}$ Así lo entiende ArRIESE Irondo, M. ${ }^{a}$ N. (2015), «Artículo 12. Derecho a contraer matrimonio» en Lagasabaster Herrarte I. (dir.), Convenio Europeo de Derechos Humanos: comentario sistemático, Madrid, Aranzadi, páginas 688 a 713, quien recuerda que la extinta ahora Comisión Europea de Derechos Humanos ya advirtió que vulneraría el artículo 12 no permitir a una persona contraer matrimonio durante el encarcelamiento o prohibirle abandonar temporalmente éste para casarse.

${ }^{90}$ Asunto Frasik c. Polonia de 5 de enero de 2000.

${ }^{91}$ Asunto Jaremowicz c. Polonia, de 5 de enero de 2010, «no pudiendo alegarse por las autoridades la ilegalidad de la unión, el carácter superficial e indigno, desde el punto de vista de la rehabilitación, ya que la relación se inició de manera clandestina contraviniendo las prohibiciones imperantes en prisión».

92 CARmona Cuenca, E. (2014). "El derecho a un recurso efectivo ante una instancia nacional. Problemas interpretativos (art. 13 CEDH)». García Roca, J. y Santolaya Machetti, P. (coords.), La Europa de los Derechos: Convenio Europeo de Derechos Humanos, Madrid, Centro de Estudios Políticos y Constitucionales, págs. 565 a 586. 
recurso interno tenga efectos suspensivos automáticos, al menos cuando esté comprometido el derecho a no sufrir malos tratos; f) exige que las sentencias internas firmes sean efectiva mente aplicadas.

En el asunto Poghosyan y Baghdasaryan c. Armenia, de fecha 12 de junio de 2012, reconoció la vulneración del artículo 13 del Convenio, por cuanto se le niega al demandante por su legislación interna de la posibilidad de un recurso que le permitiera solicitar la reparación en concepto de daño moral a consecuencia de los malos tratos sufridos. La citada resolución del Tribunal trae causa de una demanda formulada por un ciudadano armenio (Armen Poghosyan), a quien se le había negado por los órganos jurisdiccionales indemnización en vía civil por los malos tratos sufridos por la actuación de dos policías, a pesar de recaer sentencia condenatoria contra estos en un procedimiento penal. Como advierte el propio Tribunal la «violación del derecho a un recurso efectivo contenido en el artículo 13 tendrá lugar incluso sin necesidad de que se produzca la conculcación de otro precepto del Convenio"; como ocurre en este caso, donde la jurisdicción interna reconoce al demandante que ha sido objeto de malos tratos, autoinculpándose de delitos que no había cometido, por la violencia física a que fue sometido durante su estancia en las dependencias policiales.

Realiza, a nuestro juicio, una interpretación extensiva el Tribunal del artículo 13 del Convenio, al no exigirse de forma simultánea la violación de otro precepto del mismo, para declarar que se ha conculcado el "derecho a un recurso efectivo a una indemnización»" ${ }^{93}$; a pesar de que la dicción literal del susodicho artículo parece vincular el nacimiento este derecho a la vulneración de cualesquiera otro derecho reconocido en el Convenio.

Podría concluirse que el TEDH ha acudido a los artículos 5.4 y 6.1 del Convenio con preferencia sobre el artículo 13, utilizando con mayor asiduidad en las últimas resoluciones éste último precepto como derecho-garantía de los demás derechos ${ }^{94 .}$

${ }^{93}$ Debe tenerse en consideración que el artículo 3 del Protocolo núm. 7 al Convenio, reconoce «que una sentencia penal condenatoria firme resulte posteriormente anulada... la persona que haya sufrido la pena en virtud de esa condena será indemnizada conforme a ley». En el asunto Poghosyan y Baghdasaryan c. Armenia se anula la sentencia condenatoria por los órganos judiciales armenios por los delitos de violación y homicidio, sin que se reconozca en la legislación interna derecho a indemnización alguna por los cinco años y seis meses de prisión que había cumplido injustamente.

${ }^{94}$ Carmona Cuenca, E. (2014), op. cit., págs 565 a 586. 


\section{CONSIDERACIONES FINALES}

A lo largo el presente estudio hemos querido poner de relieve la inexistencia de un catálogo adecuado de derechos penitenciarios contemplados en instrumentos jurídicos internacionales de «ius cogens ", ya sean universales o regionales, que de forma integral ofrecieran un marco de garantías normativas a las personas privadas de libertad, hayan sido objeto de desapariciones forzadas o se encuentren cumpliendo penas privativas de libertad en virtud de sentencia condenatoria. Ello no es óbice para reconocer que, inserto en el proceso de humanización de los sistemas penitenciarios y de internacionalización de las garantías jurídicas de los derechos humanos, sí se hayan plasmado en tratados internacionales los derechos naturales, inalienables que no pueden desgajarse de la dignidad inherente al ser humano.

El Derecho Internacional no ha dispensado a los reclusos la protección jurisdiccional que merecen en atención a la situación de especial vulnerabilidad en que se encuentran, a pesar de seguir teniendo la consideración de ciudadanos y seguir formando parte de la sociedad. Pueden ser varias las causas que han dado lugar a este fenómeno, aunque podrían condensarse en la negativa férrea y persistente resistencia de los Estados de ceder a organizaciones o instituciones supranacionales porciones de soberanía nacional, esto es, de «ius puniendi» o derecho a castigar; lo que sobradamente explicaría que las Reglas Penitenciarias Europeas carezcan de fuerza obligatoria, al revestir la forma de simples Recomendaciones o Resoluciones emanadas del Comité de Ministros del Consejo de Europa, carentes de fuerza obligatoria, y por ende, de mecanismos que permitan a los destinatarios de las mismas, los reclusos, hacerlos efectivos ante los Estados que las inobservasen.

Y a pesar de que el CEDH no es un instrumento específico e integral de protección de los derechos de los presos, ha sido asimismo en el seno del Consejo de Europa donde ha encontrado acomodo un elevado nivel de protección jurisdiccional de los derechos humanos y libertades públicas, especialmente a través de la aplicación e interpretación por el TEDH de los preceptos del CEDH, y que no han alcanzado otras declaraciones de derechos, como la propia DUDH, como hemos tenido ocasión de constatar a lo largo del presente trabajo. El mismo TEDH se ha encargado de recordar en el asunto «El Masri c. ExRepública yugoslava de Macedonia ap. 134, que el Convenio es «un instrumento de protección de los derechos humanos, y que es crucial que se aplique de forma que garantice unos derechos concretos $y$ efectivos, y no teóricos e ilusorios». 
Es ahí donde la radica la inconmensurable labor del TEDH, quien a través de su ingente jurisprudencia, ha permitido mejorar las garantías jurisdiccionales de los reclusos, articulando una serie de mecanismos para hacerlos efectivos en el caso de que fueran desconocidos por las autoridades de los Estados Parte, forzando el reconocimiento y la positivización de algunos derechos de los reclusos en nuevos Protocolos de desarrollo del CEDH, que ya habían sido plenamente recogidos en sus pronunciamientos, evitando así que los catálogos de derechos reconocidos en aquél posean una eficacia meramente programática, como ocurre con las Reglas Penitenciarias antes aludidas. Así ha ocurrido a modo ejemplificativo, y sin ánimo exhaustivo, con los conceptos (que el propio Convenio no recoge de forma expresa) de «desaparición forzada» en relación con el derecho a la libertad del artículo 5, la nítida distinción entre la vertiente procesal y material de los actos constitutivos de tortura, o entre esta última y trato inhumano o degradante, la inversión de la regla de la carga de prueba como consecuencia de la posición de garante de los Estados Parte respecto de las personas detenidas, la necesidad de un «examen particularmente exhaustivo «; mecanismos sobre los que no vamos a volver con detenimiento para evitar reiteraciones innecesarias.

Por tanto «el desarrollo del CEDH se asienta en buena medida en el dinamismo interpretativo del TEDH... que ha propiciado una evolución de las normas extrayendo de ellas nuevas implicaciones o nuevas exigencias, haciendo asi del Convenio un instrumento de desarrollo de Derecho vivo ${ }^{95}$ ».

En este sentido, en su infatigable pretensión de erigirse en garante último de los derechos humanos en el ámbito del Consejo de Europa, ha extendido el contenido de los preceptos del Convenio y por ende sus mecanismos de protección jurisdiccional a los reclusos, a pesar de no ser este último un cuerpo normativo diseñado «ad hoc» para éstos; toda vez que ha habilitado la vía del artículo 34 del CEDH para conocer de las demandas individuales que puedan formular los presos, previo agotamiento de las vías de recurso internas que exige el artículo del Convenio o cumplimiento del principio de subsidiaridad, dado el papel subsidiario del TEDH en relación con los sistemas internos de derechos humanos. Así lo acredita por ejemplo que el número mayor de sentencias condenatorias a nuestro país en el año 2013 lo ha sido por no respetar las exigencias del artículo 6 del Convenio; o baste recordar ahora la

\footnotetext{
${ }^{95}$ AKandjI-Kombe, J.-F. (2006). «Carta Social Europea y Convenio de Derechos Humanos: Perspectivas para la próxima década». Revista de Derecho Político, núm. 67, págs. 387 a 407.
} 
excepcional trascendencia para la política penitenciaria española de la STEDH de 21 de octubre de 2013, asunto Del Rio Prada contra España.

No debemos perder de vista que la jurisprudencia contenida en las resoluciones del TEDH, al perfilar el contenido y límites de los derechos consagrados y garantizados en el Convenio, tiene necesariamente repercusión en la interpretación y aplicación que de tales preceptos efectúen los Estados Parte, hayan sido parte o no en el procedimiento en el que se hubiere dictado la sentencia. Así lo entendido nuestro Tribunal Constitucional en su Sentencia 303/1993, de 25 de octubre, al afirmar que la jurisprudencia del TEDH, incluso en los asuntos en los que España no tenga la condición de parte demandada «no solo ha de servir de criterio interpretativo en la aplicación de los preceptos constitucionales tuteladores de los derechos fundamentales», sino que al mismo tiempo «resulta de aplicación inmediata en nuestro ordenamiento». Vendría así a otorgarse una eficacia no solo inter partes de la doctrina jurisprudencial del TEDH sino erga omnes, esto es, frente a todos los Estados Parte del Convenio, aunque no hayan sido demandados en el procedimiento correspondiente.

La labor del TEDH no se agota en la mera declaración de vulneración por los Estados Parte del Convenio de los derechos consagrados en el mismo, sino que como consecuencia inextricable de la protección pretoriana que brinda a las personas privadas de libertad, recuerda incesantemente a las jurisdicciones nacionales que uno de los pilares esenciales de los Estados de Derecho es el respeto de los derechos fundamentales, incluidos los derechos de los reclusos, puesto que «la dignidad y la libertad humanas constituyen la esencia del $C E D H{ }^{96}$. De tal forma que ni siquiera supuestas razones de peso esgrimidas por las Autoridades de los Estados que contravienen el Convenio, como la lucha contra el terrorismo ${ }^{97}$ o el «secreto de Estado «pueden constituir excepciones a la escrupulosa observancia de los derechos fundamentales de quienes se encuentran recluidos.

En su intención de hacer efectivos los derechos de las personas privadas de libertad, en sus sentencias el TEDH da un paso más allá y reflexiona de lege ferenda qué medidas legislativas deben adoptar los Estados Parte para adaptar su legislación no solo a lo preceptuado en

${ }^{96}$ Así se recoge en el apartado 248 STEDH de fecha 13 de diciembre de 2012, asunto El Masri contra Ex-República Yugoeslava de Macedonia.

${ }^{97}$ En el asunto Gafgen c. Alemania señaló el TEDH que la «prohibición de maltrato es independiente de las actuaciones de la persona en cuestión o de la motivación de las autoridades. La tortura o un trato inhumano o degradante no pueden ser infligidos, ni siquiera cuando la vida de un individuo se halle en peligro. No existe ninguna excepción, ni siquiera en caso de amenaza publica hacia la vida de la nación». 
el Convenio, sino también para disertar sobre cuestiones de tal envergadura y que afectan, por ende, al status jurídico de los reclusos, como la finalidad rehabilitadora de las penas privativas de libertad ${ }^{98}$, o la más que posible colisión entre la fijación por algunas legislaciones internas de las condenas a pena perpetua y los derechos consagrados en el Convenio. Es jurisprudencia constante del TEDH que las penas privativas de libertad de duración indeterminada que no ofrezcan la posibilidad de su revisión pueden vulnerar el artículo 3 del Convenio, como pena o trato inhumano o degradante. Así lo afirmó categóricamente en el asunto A. y otros contra Reino Unido, en el asunto Kafkaris c. Chipre de fecha 12 de febrero de 2008 y Meiner c. Alemania de fecha 3 de noviembre de 2011. Doctrina esta ultima de vital repercusión para nuestro país, que ha introducido en fechas recientes en el ámbito penal y penitenciario la figura de la prisión permanente revisable ${ }^{99}$, y que sin duda ofrece serias dudas acerca de su constitucionalidad.

Nos parece acertado finalizar recordando con el profesor Reviriego Picón ${ }^{100}$, el desiderátum del Tribunal Europeo de Derechos Humanos exigiendo que «la justicia no se detenga a la puerta de las prisiones», en su Sentencia Campell y Fell v. Reino Unido de 28 de junio de 1984, que nuestro Alto Tribunal reprodujo por primera vez en la STC 2/1987, de 21 de enero, y que debe presidir el análisis, estudio o formación de la materia penitenciaria y, por ende, de los derechos de los reclusos.

${ }^{98}$ Caso Vinter y otros c. Reino Unido y en el que se remite a la Sentencia recaída en el asunto Dickinson c. Reino Unido.

${ }^{99}$ En la Exposición de Motivos de la L. O. 1/2015, de 30 de marzo, por la que se modifica la L. O. 10/1995 de 23 de noviembre, del Código Penal, se justifica la introducción en nuestro país de la figura de la prisión permanente revisable para delitos de extrema gravedad «en los que los ciudadanos demandaban una pena proporcional al hecho cometido». Sin adentrarnos más en la materia, para no exceder con mucho los límites de este trabajo, solo apuntaremos que parece que estamos en presencia de una vuelta a los fines puramente retributivos o expiatorios de las penas privativas de libertad, desoyendo el mandato resocializador del artículo 25.2 de nuestra Carta Magna.

${ }^{100}$ Reviriego Picón, F. (2008), op. cit., pág. 147. 